\title{
ALGUNAS PRECISIONES Y NUEVOS DATOS EN TORNO A LOS ALFONSO: UNA FAMILIA DE CANTEROS EN EL ARZOBISPADO DE TOLEDO (1383-1431)
}

\author{
POR \\ GEMA PALOMO FERNÁNDEZ \\ Universidad Autónoma de Madrid
}

The documents from the archives in the cathedral of Cuenca mention, among the masters working there since the first century, the names of two stonemasons: Ferrand and Juan, with the common surname «Alfonso». The latter will become «master of the construction of the church» in 1420. These two stonemasons are evidently members of the polemical family Alfonso. They were working at the same time at the Cathedral of Toledo, where they had been employed for a long time, as well as in other buildings under the orders of archibishop Pedro Tenorio. In this article, I will provide some unpublished data about this important and large clan which has produced so much confusion among the specialists.

La documentación del archivo capitular conquense - libros de fábrica y actas capitularesincluye, entre los maestros activos en los talleres de la catedral desde la primera década del siglo XV, el nombre de dos canteros - Ferrand y Juan — con el apellido común Alfonso. Este último llegará además a convertirse, ya en en 1420, en «maestro de las obras de la iglesia». Es evidente que se trata de dos miembros de la polémica familia de los Alfonso, que en los mismos años, y desde tiempo atrás, participaban en las obras que entonces se llevaban a cabo en la catedral metropolitana y en otras emprendidas bajo el patronazgo, o la influencia, del poderoso arzobispo Pedro Tenorio. Es más, ambos pueden identificarse con los dos maestros del mismo nombre citados por Ceán, como veremos, y desde entonces en otras ocasiones - especialmente Juan Alfonso-, pero siempre con gran imprecisión. La trascendencia de esta amplia familia, cuyo quehacer se extenderá por buena parte de Castilla durante casi un siglo, y la confusión que ha generado entre los especialistas nos ha animado a centrar en ella nuestra atención, rastreando en sus orígenes y tratando de seguir su actividad, cuando las fuentes nos lo permiten, con el fin de situar a nuestros dos maestros. El punto de partida ha sido una lectura minuciosa de los libros de la sección de Obra y Fábrica conservados en el archivo capitular de Toledo ${ }^{1}$ para el periodo $1383-1432^{2}$.

\footnotetext{
1 En adelante se citara A.C.T.; O.F.

2 Desde este último año, la información se interrumpe hasta 1448. También faltan los libros comprendidos entre 1383 y 1418. Existe catálogo de los fondos de Obra y Fábrica, apoyo inestimable para cualquier investigación: CARMEN TORROJA MEnÉndez, Catálogo del Archivo de Obra y Fabrica de la catedral de Toledo, Toledo 1977.
} 
Efectivamente, un Fernando ( Ferrand») Alfonso aparece entre los menestrales que trabajan en el taller toledano a lo largo del año 1383, cobrando cuatro maravedís y medio por día de trabajo. Para entonces era el maestro Enrique quien se hacía cargo de la dirección de las obras, recibiendo por su labor cinco maravedís diarios ${ }^{3}$. Es posible que se trate de la misma persona que un «maestro de la obra» Ferrand Alfonso que aparece firmando una escritura en el año $1379^{4}$, aunque este extremo, con los datos que tenemos, no se puede asegurar, máxime cuando en 1383 no recibe dicha calificación ${ }^{5}$. En este año la primera vez que se cita a Fernando Alfonso es en los asientos correspondientes al mes de enero y, desde entonces, en los meses sucesivos ${ }^{6}$. A partir de julio, junto a éste aparece un «Ferrand Alfonso el moço» — tal vez su hijo ${ }^{7}$ - a quien corresponden cada día tres maravedís y medio ${ }^{8}$. En diciembre encontramos además referencia a un Pedro Alfonso, que cobra cuatro maravedís; de él se dice que es her-

3 A.C.T.; O.F. 760 (1383), f. 1 r. Cfr. J. M. ${ }^{\text {a }}$ AzcÁrate, «Alvar Martínez, maestro de la catedral de Toledo», Archivo Español de Arte, n. ${ }^{\circ} 89,1950$, p. 8. n. 15 bis. De este maestro Enrique no sabemos nada, ni de su biografía personal ni de la parte de la fábrica catedralicia que pudiera atribuirse a su responsabilidad. El único dato con que contamos, indirecto y cuatro décadas posterior, es una anotación en los libros de Fábrica desde 1424 hasta 1429, que nos indica que habitaba en una casa, propiedad de la Obra, que después pasó a ocupar el maestro Alvar Martínez como gracia "por razón del maestrazgo» (O.F. 762, fol. 2 vto.; 763, fol. 2 vto.; 764, fol. 2 vto.; 765, fol. 2 vto. y 767 fol. 2 vto.). Por su parte, M. ${ }^{a}$ T. PÉREZ Higuera lo identifica con un «maestro Anrique», escultor, citado por Ceán, que, malinterpretando una noticia —una carta de pago fechada en 1380 - le atribuye el sepulcro de Enrique II en la capilla de los Reyes Nuevos (J.A. CEÁN BERmúdeZ, Diccionario histórico de los más ilustres profesores de las Bellas Artes en España, 1800 (ed. 1965), t. I, pp. 35-36). En opinión de la autora, sin embargo, no existiría tal escultor sino que se trataría de aquel mismo personaje que, en virtud de su cargo de maestro mayor, debió ocuparse de acondicionar la catedral y la capilla para recibir y dar sepultura a los restos reales, trasladados desde Valladolid precisamente en 1380 («Los sepulcros de Reyes Nuevos (catedral de Toledo)», Tekné, n. ${ }^{\circ} 1,1985$, pp. 137-138).

4 A. Sánchez-Palencia Mancebo, «La escuela toledana de don Pedro Tenorio», Anales Toledanos, XXVI, 1989, pp. 8384. La autora lo localiza en otra serie documental, los protocolos del archivo de Obra y Fábrica, y apunta que sin duda se trata del antecesor de Rodrigo Alfonso, posiblemente su tío, sin advertir de la presencia de varios artífices de este nombre en las mismas fechas (Rodrigo Alfonso «el viejo» y Rodrigo Alfonso; véase infra n. 32). En cambio, señala que no debe tratarse del mismo Ferrand Alfonso cuyo trabajo se documenta años después (1425). Por otra parte, junto con el maestro Ferrand Alfonso firmaba la escritura mencionada otro pedrero con el mismo patronímico: Diego Alfonso. Este último había aparecido ya un año antes, en 1378, arrendando unas casas al cabildo cerca del baño del arzobispo; de él se dice que era hijo de Pedro Alfonso y que estaba casasado con Francisca Fernández. Por fin, un Juan Alfonso, pedrero, es testigo en una escritura de 1375 junto con los también pedreros Diego González y Joán González y los albañiles Alfonso Ferrández y Pedro García (Ibidem., idem., p. 130).

${ }^{5}$ Bien es cierto que este detalle, por sí sólo, no significa nada, ya que, como es sabido, su aplicación en la Edad Media es sumamente arbitraria. Pero el jornal que por su trabajo recibe en 1383, cuatro maravedís y medio, no sólo está por debajo del que corresponde a quien ostenta la titularidad de la obra, el maestro Enrique, que cobra cinco maravedís, sino también del que reciben otros «menestrales del taller» como Diego González, Francisco Martínez, Rodrigo Alfonso «el viejo», Johan González, Pedro Rodríguez, Antón Rodríguez, Pedro Martínez, Johan Ruyz o Ferrand González (A.C.T., O.F., 760 (1383), f. 2r.), Bartolomé de Brujas y Luis de Brujas (Idem., f. 13 v.), o Diego Alfonso (Idem., ff. 23 r. y 26 r.), todos ellos cinco maravedís.

${ }^{6}$ A.C.T; O.F. 760 (1383), ff. 3 r., 6 v., 10 v., 14 v., 17 v., 20 v., 23 v., 26 v., 32 v., 35 v., 38 v.

7 No obstante, también podría serlo del Diego Alfonso que junto con el maestro Ferrand Alfonso firmaba una escritura en 1379 y que en 1383 cobra cinco maravedís (véase supra $\mathrm{n} .4$ y 5 ).

8 A.C.T.; O.F. 760 (1383), ff. 23 v., 32 v., 35 v.

No sabemos si este Fernando Alfonso «el moço» es la misma persona que un tal «Ferrand Alfonso del Arzobispo», cuya presencia en la obra de Toledo está documentada, al menos, en el mes de julio, y que recibe por su trabajo la misma cantidad que aquél: tres maravedís y medio cada día (A.C.T., O.F. 760, f. 23 v.).

Por otra parte, muchos años después, con fecha 17 de marzo de 1425, Alfonso Martínez, tesorero y obrero de la iglesia de Toledo, paga a cuatro peones - Fernando Alfonso, Alfonso de Toledo, Alfonso García y Alfonso Rodríguez-, vecinos de Toledo, diez maravedís de jornal por cada uno de los seis días de la semana, de lunes a sábado, "que andudieron arrancar e desbastar piedra en la cantera de Oliuelas para las obras de la dicha eglesia» (A.C.T., O.F. 763 (1425), f. 76 v.). Todos ellos continuarán trabajando en la mencionada cantera en los días y meses siguientes. No sabemos que relación puede tener este Fernando Alfonso, peón, con el maestro Fernando Alfonso, o si pudiera identificarse con su posible hijo Fernando Alfonso el mozo, pues no hay más datos al respecto. Lo mismo sucede con un Fernando Alfonso "gallego» que en marzo de 1429, en compañía del carpintero Fernando García, labra y asienta madera para las ruedas de las campanas de la torre del Reloj: «Iten Ferrant Garçia, carpintero, e Ferrant Alfonso gallego, que labraron medio día e asentaron madera para las ruedas de las canpanas de la torre del Reloj. E dieronles de jornal al dicho Ferrant García diez e al dicho Ferrant Alfonso çinco, que son quinçe» (A.C.T., O.F. 767 (1429), f. 102 r). 
mano de Fernando Alfonso, suponemos que de «el mozo», puesto que éste sigue percibiendo la misma cantidad: tres maravedís y medio por día; por tanto, medio menos que su hermano Pedro ${ }^{9}$.

En definitiva, varios miembros de la misma familia — Diego Alfonso, Rodrigo Alfonso «el viejo», Rodrigo Alfonso, Fernando Alfonso y sus posibles hijos, los hermanos Fernando Alfonso «el mozo» y Pedro Alfonso- trabajan este año en el taller que dirige el maestro Enrique. Sin embargo, este último, en una fecha que desconocemos, pero en cualquier caso a lo largo de 1383, deja el maestrazgo, ya que en el último folio del libro de fábrica de dicho año una anotación nos indica: «Esta es la taxaçión que fizo Ferrand Alfonso, maestro de la obra en la cantera $[\ldots]\rangle^{10}$.

Años después, en 1418, la constatación de la labor de un Juan Alfonso, pedrero, «fijo de Ferrand Alfonso, maestro que fue de la obra» ó «fijo del maestro Ferrand Alfonso» ${ }^{11}$, corrobora el ejercicio del cargo por parte de éste que, como acabamos de ver, lo asume en 1383. De este modo, además, Juan Alfonso se suma a la familia de pedreros apellidados Alfonso, que no sólo trabajarían en los talleres de la catedral toledana sino que habrían de extender su maestría por su área de influencia ${ }^{12}$.

Pero ¿qué es lo que sabemos de ellos? En realidad muy poco; los datos de que disponemos, si bien relativamente abundantes en lo que a referencias documentales se refiere a lo largo de un periodo cronológico concreto (1383-1431), son enormemente confusos y, en especial, poco precisos a la hora de intentar establecer cualquier tipo de relaciones familiares. Mas aún si tenemos en cuenta que el número de personajes con este patronímico es todavía bastante más amplio de lo que hasta ahora hemos tenido ocasión de ver, que lo comparten miembros que desempeñan oficios distintos (canteros, carpinteros, albañiles, pintores) y niveles diferentes dentro de la escala profesional (maestros, peones), amén de algún que otro miembro del cabildo. A lo largo de las páginas siguientes trataremos de esclarecer en lo posible la cuestión, o al menos aproximarnos tanto como nos lo permita la información con que contamos.

\section{FERNANDO Y RODRIGO ALFONSO}

La personalidad del maestro Fernando Alfonso nos es prácticamente desconocida. En 1800 Ceán Bermúdez se refería a él como padre del Juan Alfonso que en 1418 colabora en la decoración de la fachada principal de la catedral de Toledo, aunque nada añade sobre el primero ${ }^{13}$. Basándose seguramente en este dato, Vicente de la Fuente, en una anotación a la obra de Quadrado, incluía una relación de artífices en la que figuraba un Juan Alfonso, hijo de Fernando Alfonso, sin aportar, sin embargo, más información sobre ninguno de estos dos personajes ${ }^{14}$.

\footnotetext{
${ }^{9}$ "P. ${ }^{\circ}$ Alfonso labró dos días a IIII maravedís cada día, que montan VIII maravedís. Reçibiólos su hermano Ferrant Alfonso». Y a continuación; "Ferrant Alfonso, su hermano, labró X días y medio a III maravedís y medio cada día, que montan XXXVI maravedis, VII dineros y III meajas» (A.C.T.; O.F. 760 (1383), f. 38 v.; asiento correspondiente al mes de diciembre). Volvemos a encontrarlo más adelante, en 1418, cuando se reanuda la serie de libros de fábrica interrumpida entre 1383 y esta última fecha, trabajando como pedrero en la capilla de San Pedro, en las puertas del Perdón y en las paredes del claustro: O.F. 761 (1418), ff. 62 v., 76 v. y 99 r

${ }^{10}$ A.C.T.; O.F. 760 (1383), f. 75 v. El final de la frase aparece borrado.

$"$ A.C.T., O.F. 761 (1418), ff. 81 r., 123 v., 152 r./v. Del mismo modo, más adelante: O.F. 765 (1427), f. 167 v., O.F. 766 (1428), f. 181 v., O.F. 767 (1429), f. 172 r. y O.F. 768 (1431), f. 153 v. y 191 r.

12 Junto con los miembros de esta familia mencionados, encontramos también referencia a un Fernando Sánchez, yerno (y. ${ }^{\circ}$ ) de Juan Alfonso (A.C.T., O.F. 761 (1418), f. 143 r.).

13 Ceán Bermúdez, Diccionario, op. cit., t. I, p. 17.

14 J. M. ${ }^{a}$ Quadrado, Toledo y Ciudad Real, en «España. Sus Monumentos y Arte, su Naturaleza e Historia», Castilla la Nueva III, 1886 (ed.facs. 1978), p. 180, n. 1.
} 
Elías Tormo lo confunde con su homónimo Ferrand González, autor de los sepulcros de Pedro Tenorio y Vicente Arias, así como de las imágenes de la Anunciación en la portada de la Capilla de San Blas ${ }^{15}$. Y, como ya advirtió Pérez Higuera, aunque el propio Tormo rectificó el error en una nota del mismo artículo ${ }^{16}$, el equívoco tendría sus consecuencias posteriores, provocando identificaciones erróneas como la que realiza F. Almarche Vázquez. Este autor asoció a Ferrand González con el Ferrand Alfonso documentado en un contrato que se fecha en Valencia en 1396, y que no es otro que el maestro del mismo nombre que trabaja en Toledo en 1383 y los años siguientes ${ }^{17}$. En 1914 Pérez Sedano, a partir de los datos de Ceán, lo cita también como padre de un maestro Juan Alfonso que en 1418 trabaja en la portada del Perdón y, más tarde, en las armas de la torre del Reloj; pero, una vez más, nada se dice con respecto a la figura de Fernando Alfonso ${ }^{18}$. Más tarde será Azcárate el primero en localizarlo, precisamente trabajando junto al maestro Enrique en 1383, haciendo además referencia a su hijo Juan y reclamando nuestro interés por la gran confusión existente, por parte de la crítica especializada, en torno a la familia Alfonso ${ }^{19}$.

$\mathrm{Si}$ abandonamos ahora la historiografía y recapitulamos sobre los datos documentales antes expuestos, de él sabemos - al margen de que se trate o no de la misma persona documentada en 1379-que en 1383 trabaja por cuatro maravedís y medio la jornada bajo la dirección del maestro Enrique, junto con un grupo amplio de pedreros, de los cuales más de uno compartía su apellido. Entre ellos destaca, sin duda, Rodrigo Alfonso — sobre el que enseguida volveremos-, cuyo posible grado de parentesco con el primero sigue siendo para nosotros una incógnita. Pero hemos de mencionar también a otros, como Diego Alfonso, que a cambio de cinco maravedís diarios participa en las tareas del taller ${ }^{20}$.

A Ferrand o Fernando podemos atribuirle con toda seguridad un hijo, Juan Alfonso, a quien en ocasiones se llamará «el mozo», y posiblemente otros dos: Fernando Alfonso «el mozo» y su hermano Pedro Alfonso ${ }^{21}$. Nos consta además que disponía de al menos un criado, de nombre Rodrigo (¿Piconero?), cuya remuneración diaria es de quince dineros ${ }^{22}$. Finalmente, de acuerdo con los datos indicados, parece que en algún momento del citado año sustituye al maestro Enrique en la dirección de las obras de la catedral.

No obstante, la crítica especializada no ha tenido en absoluto clara la posible maestría de este personaje ${ }^{23}$. Se ha dicho que de asumirla en 1383 debío abandonarla muy pronto por razones que desconocemos, puesto que cuando se pone la primera piedra del claustro bajo, el 14

\footnotetext{
15 E. Tormo y Monzo, «Gerardo Starnina en España», Boletín de la Sociedad Española de Excursiones, 1910, p. 88.

${ }^{16}$ Idem., p. 88 , n. 1.

17 F. Almarche Vázquez, «Maestre Esteve de Rovira en Chipre, pintor trecentista desconocido», Archivo de Arte Valenciano, 1920, p. 12. Cfr. M. ' T. Pérez Higuera, «Ferrand González y los sepulcros del taller toledano (1383-1410)», Boletín del Serminario de Estudios de Arte y Arqueología, Valladolid, t. XLIV, 1978, p. 130, n. 4.

${ }_{18}$ F. Pérez Sedano, Notas del archivo de la catedral de Toledo, «Datos documentales para la Historia del Arte español», t. I, Madrid 1914, pp. 7 y 9.

19 J. M. ${ }^{a}$ AzCÁRATE, «Alvar Martínez...», op. cit. p. 8, n. 15 bis.

20 A.C.T., O.F. 760 (1383), f. 20 r., 26 r (Véase supra, notas 4 y 5). Casi medio siglo más tarde, en 1428, encontramos de nuevo referencia a un Diego Alfonso, pedrero y criado de Pedro Gutiérrez Nieto, entregando material labrado, procedente de las canteras de Regachuelo, para las torres de las Campanas y del Reloj (O.F. 766 (1428), f. 198 r.). Ignoramos si se trata de la misma persona, aunque el prolongado lapso de tiempo transcurrido entre las dos fechas indicadas lo hace, cuanto menos, difícil. Aún otro Diego Alfonso (¿el de 1428?) trabajará a partir de 1453 en la Puerta Nueva o de los Leones, bajo las órdenes de Hanequín de Bruselas; consta su presencia en: O.F. 772 (1453); 773 (1454); 774 y 775 (1458).

21 Véase supra, n. 7.

${ }^{22}$ Conocemos dicha relación entre ambos porque en el referido libro de cuentas aparece citado como «Rodrigo Piconero(?) de Ferrando Alfonso»; otras veces porque es este último, su «amo», quien recoge su jornal: «..recibiólos Ferrando Alfonso, su amo» (A.C.T., O.F. 760 (1383), ff. 6 r., 11 r., 15 r., 18 r., 21 r., 24 r., 27 r., 30 r.).

${ }^{23}$ De hecho, M. ${ }^{a}$ T. PÉrez Higuera pensaba que por error se le viene considerando maestro mayor de la obra de la catedral. («Ferrand González...», op. cit. p. 130, n. 4)
} 
de agosto de 1389, según indican los Anales Toledanos ${ }^{24}$, figura al frente el maestro de obras de la catedral - tal y como han asegurado buena parte de los especialistas- Rodrigo Alfonso, el mismo a quien el arzobispo Tenorio encarga su capilla de San Blas, y cuya actividad constructiva se documenta a partir de $1398{ }^{25}$ (fig. 1). Sin embargo, en realidad los Anales Toledanos indican la fecha de colocación solemne de la primera piedra, pero nada dicen con repecto a su maestro mayor. Tampoco lo hace Narbona en su biografía del arzobispo Tenorio ${ }^{26}$. Parece, por tanto, que el origen de esta vinculación entre Rodrigo Alfonso y el claustro patrocinado por Pedro Tenorio se encuentra en una sugerencia de Llaguno ${ }^{27}$, que debió basarse en el hecho de que sí este documentado como maestro mayor de la capilla de San Blas, realizada bajo el patronazgo del mismo arzobispo, de modo que no habría de extrañar que lo fuera también del claustro. Sin embargo, nada impide, dada la ausencia de cualquier tipo de apoyo documental, que para entonces fuera todavía «maestro de la obra» Fernando Alfonso, que consta ya como tal en 1383. En todo caso, desde Llaguno la atribución a Rodrigo Alfonso de la dirección de las obras del claustro ha venido siendo reiterada una y otra vez, empezando, aún en el siglo XIX, por José Amador de los Ríos ${ }^{28}$, José María Quadrado ${ }^{29}$ y Ramón Sixto Parro ${ }^{30}$; y, entre los contemporáneos, por Torres Balbás ${ }^{31}$.

La primera mención de Rodrigo Alfonso la encontramos en el libro de fábrica de 1383; entonces formaba parte, como Fernando Alfonso, de los menestrales del taller que trabajaba bajo la dirección del maestro Enrique. En realidad no se trataba de uno, sino de dos personajes de idéntico nombre, a los que tan sólo permite distinguir el apelativo "el viejo» que a veces

${ }_{24}$ «Anno de mill e trezientos e ochenta e nueve del nascimiento de nuestro Salvador Jesuchristo, regnando el rey don Johan, fijo del Rey don Henrique e nieto del Rey don Alphonso, en Castilla y en Portugal, el Arzobispo don Pedro Tenorio comenzo la claustra de la Eglesia mayor de Toledo, e puso en ella la primera piedra en la vigilia de Santa María de Agosto del anno sobredicho, seyendo el Arzobispo de la dicha çibdat...» (Anales Toledanos III, n. X, en E. FLóREZ, España Sagrada, T. XXIII, p. 421).

${ }^{25}$ Debemos a A. SÁnchez-Palencia el estudio y publicación de la documentación referente a la capilla de San Blas en la sección de Obra y Fábrica del archivo capitular de Toledo: «La capilla del Arzobispo Tenorio», Archivo Español de Arte, XLVIII, 1975, pp. 27-42; «Fundaciones del Arzobispo Tenorio: La capilla de san Blas», Rev. Provincia, n. ${ }^{\circ} 89$, $1975 ;$ Fundaciones del Arzobispo Tenorio: la capilla de San Blas en la catedral de Toledo, Toledo 1985. También -aunque más resumido- en Vida y empresas del arzobispo don Pedro Tenorio, Toledo 1988, pp. 29-33. Más tarde lo recoge A. Franco Mata en Arquitecturas de Toledo, del románico al gótico, Toledo 1992, especialmente pp. 450-455, y «El obispo Pedro Tenorio: vida y obra», en La idea y el sentimiento de la muerte en la historia y el arte de la Edad Media (II), Santiago de Compostela 1992, pp. 73-93 (para la capilla especialmente, p. 81 y ss).

${ }^{26}$ E. Narbona, Don Pedro Tenorio, arzobispo de Toledo, Toledo 1624; sobre la fábrica del claustro ver pp. 98-103.

27 «...pero siendo Rodrigo Alfonso maestro mayor de la iglesia de Toledo, parece que se le puede atribuir la traza y disposición de otros que mandó hacer el arzobispo don Pedro Tenorio. Uno de los más memorables fue el claustro de aquella iglesia, con la capilla de San Blas sita en él, cuyas obras se empezaron el 14 de agosto del año 1389, poniendo el mismo arzobispo la primera piedra» (E. LlaGuno y Almirola, Noticias de los arquitectos y arquitectura de España desde su restauración., Madrid 1829, (ed. 1977), t. I, pp. 77-78).

${ }_{28}$ J. AMADOR DE Los Ríos, Toledo pintoresca o descripción de sus más célebres monumentos, Madrid 1845, p. 105: «Fue el claustro edificado por don Pedro Tenorio, durante el tiempo en que tuvo la gobernación del reino de Castilla, en la minoridad de Don Juan I, añadiéndose el segundo cuerpo en la época del Cardenal Cisneros. Comenzóse el primero en 1389, siendo maestro mayor de la Santa Iglesia Rodrigo Alfonso, quien debió dirigir su fábrica, digna en verdad de tan suntuoso templo».

${ }_{29}$ J. M. ${ }^{a}$ Quadrado, Toledo, «Recuerdos y Bellezas de España. Castilla la Nueva II», 1853, p. 392: «... monumento del poderoso, cuanto espléndido, arzobispo Tenorio, y obra, según se cree, de Rodrigo Alfonso, insigne arquitecto de la Cartuja del Paular».

${ }^{30}$ R. S. PARro, Toledo en la mano o descripción histórico-artística de la magnífica catedral y los demás célebres monumentos, Toledo 1857, t. I, p. 66: «No ha querido la incurria de aquella época de guerras y trastornos que nos quedase memoria puntual de los arquitectos que sucediesen a Petrus Petri en la dirección de la obra de esta iglesia desde el fallecimiento de aquél hasta cien años después, que encontramos ya a un Rodrigo Alfonso, maestro mayor de la Catedral, que hubo de ser quien trazase y dirigiese en tal concepto la construcción del claustro bajo, cuya primera piera colocó el arzobispo don Pedro Tenorio, también en 14 de Agosto de 1389».

31 L. Torres Balbás, Arquitectura gótica, «Ars Hispaniae». vol. VII, Barcelona 1952, p. 237: «También carecen de tracerías los arcos del claustro de la catedral de Toledo, cuya primera piedra, según los 'Anales Toledanos', puso en 1389 el arzobispo Don Pedro Tenorio, cuyo escudo figura en la clave de sus bóvedas...; su primer maestro fue Rodrigo Alfonso». 
acompaña a uno de ellos, así como la cantidad que por día de trabajo recibía cada uno: cinco maravedís y cuatro maravedís y medio respectivamente, de modo que al más joven correspondía idéntico jornal que a Fernando Alfonso ${ }^{32}$. Luego, a partir de 1418 —en 1418, 1425, 1429 , 1431 y 1432 - se cita también con cierta frecuencia a un tal «Alfonso Rodríguez, fijo del maestro Rodrigo Alfonso» ${ }^{33}$, aunque para entonces ya era maestro de obras de la catedral de Toledo Alvar Martínez ${ }^{34}$. Recordemos que en estas mismas fechas también a Juan Alfonso el mozo se le identificaba como hijo de «Ferrand Alfonso, maestro que fue de la obra», de manera que tenemos constancia de que ambos personajes - Fernando y Rodrigo Alfonso- alcanzaron dicha categoría profesional en la cantería de Toledo y que los dos debieron desempeñarla en fechas muy próximas.

Parece ser, por tanto, que Rodrigo sucedió a Fernando Alfonso en el cargo en una fecha indeterminada, pero en todo caso después de 1383 y no mas allá de 1398, momento en que el primero consta ya como maestro en relación con las obras de la capilla de San Blas ${ }^{35}$. Cabe también la posibilidad de que ambos lo compartieran, al menos durante cierto periodo de tiempo, como sabemos que sucede en otras ocasiones ${ }^{36}$.

32 «Rodrigo Alfonso el viejo ha de aver cada día V maravedís»; más adelante se anota a Rodrigo Alfonso con la asignación correspondiente: cuatro maravedís y medio (ver A.C.T., O.F. 760, f. 2 r./v., 6 r., 9 v., 10 r., 14 r., 17 r., 20 r/v., 23 r., 26 r., 29 r., 32 r., 35 r., 38 r.). El apelativo «el viejo» no siempre acompaña al primero, pero la suma que recibe por cada día que trabaja nos indica de quién se trata.

Tiempo después, siendo ya maestro mayor de la catedral de Toledo, le atribuye también Llaguno la traza de la iglesia y monasterio de Nuestra Señora del Paular (E. Llaguno y Amirola, Noticias,..., op. cit., t. I. 77), atribución recogida por la historiografía posterior (QUADRADo, Toledo, op. cit., p. 392), que además le responsabiliza de otras obras auspiciadas por el arzobispo Tenorio, fundamentalmente - además del claustro de la misma catedral—, la colegiata de Talavera y la iglesia jerónima del monasterio de Nuestra Señora de Guadalupe (L. Torres Balbás, Arte almohade. Arte nazarí. Arte mudéjar, «Ars Hispaniae», vol. IV, Barcelona 1949, p. 271 y, aunque de modo confuso y con ciertas dudas entre éste y Fernando Alfonso, en Arquitectura gótica, op. cit., p. 170; también por C. VIzUETE MENDOzA, Guadalupe: un monasterio jerónimo (1389-1450), «Antigua et Medievalia», Madrid 1988, p. 38.). Esta última atribución (la iglesia del monasterio de Guadalupe) ha sido adscrita por otros a Juan Alfonso, como veremos después.

33 A.C.T., O.F. 761 (1418), f. 136 r.; 763 (1425), f. 184 r. y 190 v; 767 (1429), f. 1 v.; 768 (1431), f.167 r.; 769 (1432), f. 153 r. Por lo demás, es difícil saber si este Alfonso Rodríguez tiene alguna relación, o incluso si se puede identificar con el Alfonso, cuñado del maestro (Hanequín de Bruselas), que trabaja en la catedral en 1448 y 1453 (J. M. ${ }^{2}$ de AzCÁRATE, «El maestro Hanequín de Bruselas», Archivo Español de Arte, XXI, 1948, p. 177). En todo caso, algunos miembros de la familia aún estaban activos en 1463, fecha en que se paga a un «Rodrigo, fijo de Diego Alfonso, veçino desta çibdad» ciertas piezas que había labrado para la Puerta de los Leones (F. Pérez Sedano, Notas del Archivo, op. cit., p. 15; M. ZARCo DeL VALle, Documentos de la catedral de Toledo, vol.I, en «Datos documentales para la Historia del Arte español», t. II, Madrid 1916, p. 14). Este Rodrigo aparecía por primera vez en 1454, junto con su padre, trabajando en la obra de la misma portada bajo la dirección de Hanequín; entonces era todavía mozo, y como tal recibía el jornal correpondiente, 15 maravedís (A.C.T., O.F. 773, f. 221 r.); en 1458 aún no había alcanzado la categoría de maestro (O.F. 774).

34 «Desaparecidos los libros de fábrica de los primeros años del siglo XV, sólo sabemos que en 1418 ya era Alvar Martínez maestro de las obras de la Catedral de Toledo, cobrando cinco maravedís diarios por el maestrazgo, más los diez cahíces de pan por mitad trigo y cebada, según era lo usual en el siglo anterior y lo será hasta finalizar el siglo XV». ( $\mathrm{J}$. M. a AzCÁRATE, «Alvar Martínez...», op. cit., pp. 1-2). Véase también, del mismo autor, La arquitectura gótica toledana del siglo XV, Madrid 1958, pp. 10-13.

35 A todo ello podemos añadir otro dato que desvela que Rodrigo seguía detentando aún la categoria de «maestro» de la obra en 1411. El 24 de marzo de este año su mujer, Marina Gómez, y la hermana de ésta, Catalina, vendían unas casas en la colación de San Miguel. En la carta de venta Marina aparece identificada como «muger de Rodrigo Alfonso, maestro de la obra de la iglesia cathedral de Santa María de Toledo» (A.H.N. Clero. Toledo, Carmelitas, Leg. 1900, perg. 13. P. Citado por: J. Rius SERRA, «Subsidios para la historia de nuestra cultura. II (siglos XIV al Xvi)», Archivo Español de Arte y Arqueología, n. ${ }^{\circ} 13,1929$, doc. LXXVI, p. 255).

${ }^{36}$ Uno de los primeros ejemplos documentados corresponde a la catedral de Palencia, donde durante dos meses, entre el 16 de septiembre y el 15 de noviembre de 1443, compartieron el cargo los maestros de cantería Gómez Díaz de Burgos - que ya lo venía desempeñando desde 1430 y lo mantendría, seguramente, hasta su muerte en 1466- y Pedro Jalop, explicándose la incorporación de este último como una necesidad derivada de un mayor volumen de obras, o como el recurso a alguien, tal vez de mayor prestigio, que orientase una nueva etapa en la construcción de la catedral, quizá modificando sus trazas (R. Martínez, «Gómez Díaz de Burgos (1430-1466), maestro mayor de la Obra de la catedral de Palencia», Publicaciones de la Institución Tello Téllez de Meneses, 58, 1988, pp. 418-419; Ibid., La catedral de Palencia. Historia y Arquitectura, Palencia 1988, pp. 40, 49 y 107-108; Ibid., «La catedral y los obispos de la Baja Edad Media», Jornadas 
Con respecto a Fernando Alfonso, a los datos que acabamos de apuntar podemos añadir su presencia en Valencia en 1396 y su participación documentada en las obras de una catedral estrechamente relacionada con la toledana, de la que era sufragánea: la de Cuenca.

La estancia del maestro en la ciudad mediterránea — quizá trabajando temporalmente- nos la da a conocer un contrato, fechado en Valencia a 13 de junio de 1396, por el que un tal Ferdinando Alfonso, lapicida y vecino de la ciudad de Toledo, entrega en custodia al posadero Simón Armengol veintitrés florines de oro del cuño de Aragón, que debía recoger el día de la fiesta de la Asunción del mes de agosto. El 28 de este mes nuestro Fernando Alfonso otorga carta de devolución al citado posadero ${ }^{37}$. Es más que probable que se trate de la misma persona que un Ferrand Alfonso, cuyo trabajo como cantero se documenta - aunque de forma discontinua - en la Torre de Serranos entre agosto de 1395 y enero de $1398{ }^{38}$.

Tampoco son mucho más indicativos los datos con que contamos acerca de su participación al servicio de la Obra de la catedral de Cuenca. Así, nos llamó la atención encontrar, entre los asientos correspondientes a los años de 1405 y 1407, varios pagos a un Ferrand Alfonso, del cuál no se especifica el cargo o estatus profesional y que, al parecer, trabajaba en diversas obras de cantería en el «corral» de la iglesia (entre ellas cinco almenas y el levantamiento de una pared), razón por la que se le entregan dieciseis maravedís diarios ${ }^{39}$. Las lógicas dudas que se nos puedan plantear en principio con respecto a la identificación de ambos maestros -el de Toledo y el de Cuenca- como una misma persona, parecen despejarse cuando constatamos la presencia de su hijo Juan Alfonso, con explícita alusión a su origen toledano, como comprobaremos enseguida. Tratemos previamente de aclarar la personalidad, formación y producción artística atribuíble a este maestro, más significativa y mejor conocida que la de su padre.

\section{JUAN ALFONSO «EL MOZO» ${ }^{40}$}

Ceán Bermúdez incluyó en su Diccionario un Juan Alfonso, «escultor, hijo del maestro Ferrand Alfonso y uno de los artistas que trabajaron en el año 1418 en el adorno de la facha-

sobre la catedral de Palencia, 1 al 5 de agosto de 1988, Valladolid 1989, p. 52; Ibid., La arquitectura gótica en la ciudad de Palencia (1165-1516), Palencia 1989, p. 163, 167 y apéndice documental 10. p. 190).

Años más tarde encontraremos esta situación en el Palacio del Infantado de Guadalajara y en San Juan de los Reyes -

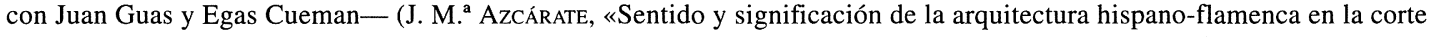
de Isabel la Católica», Boletín del Seminario de Estudios de Arte y Arqueología, XXXVII, Valladolid 1971, pp. 208 y 222223; R. Domínguez Casas, Arte y etiqueta de los Reyes Católicos. Artistas, residencias, jardines y bosques, Madrid 1993, pp. 32, 39, 41), así como en las catedrales de Toledo - Enrique y Antón Egas- y Sevilla, a partir de 1472, al considerar el cabildo que las obras iban excesivamente lentas (L. Torres BALBÁs, Arquitectura gótica, op. cit., p. 282; J. M. ${ }^{a}$ AzCÁRATE, «Antón Egas», Boletín del Seminario de estudios de Arte y Arqueología, XXIII, Valladolid 1957, pp. 11-12; F. ARRIBAS ArranZ, «Noticias sobre San Juan de los Reyes», Boletín del Seminario de estudios de Arte y Arqueología, XXIX, Valladolid 1963, pp. 56-57; R. Domínguez Casas, Arte y etiqueta, op. cit. pp. 28, 37, 40, 42, 43, 46 y 48).

${ }^{37}$ Colegio de Corpus Cristi. Protocolo de Juan de Aguilar. Sign. 870. Documentos publicados por F. AlmarChe VázQuez, «Mestre Esteve Rovira...» op. cit., p. 12.

38 Sotsobrería de Murs $i$ Valls. Quiero expresar mi agradecimiento al profesor René Carrasco que amablemente me ha facilitado esta noticia. Igualmente al profesor Amadeo Serra, que me comunica haber documentado un Rodrigo Alfonso con el título de «mestre» trabajando en Valencia en 1447 por cuatro sueldos y seis dineros diarios (Archivo del Reino de Valencia, Mestre Racional, n. ${ }^{\circ}$ 9135, f. 29 r.), lo que, junto con la también constatada actividad de otros miembros de esta misma familia (Johan Alfonso en 1452; A.R.V., Mestre Racional, n. ${ }^{\circ} 11.608$, f. 1 v.), confirma su contribución a la arquitectura valenciana de este periodo.

39 Archivo capitular de Cuenca (en adelante, A.C.C). Fábrica, 7, f. 30 v. y sign. II.8, fols. 22 v. y 22 bis r. Véase en Apéndice, doc. n. ${ }^{\circ} 1$.

${ }^{40}$ La identificación de este maestro - a quien localizamos en Toledo desde 1399- ha sido enormemente confusa. En primer lugar por la proliferación de miembros, tal vez de una misma familia, aunque no necesariamente, con el apellido o el nombre Alfonso a lo largo de estos años. En segundo lugar por la frecuencia de este nombre, que además encontramos varias veces entre los artífices de los distintos oficios que en las mismas fechas trabajaron en la catedral: Juan Alfonso 
da principal de la Catedral de Toledo» ${ }^{41}$. Por su parte, las Noticias de los Arquitectos de Llaguno y Ceán nos aportan nuevos datos, emparentándolo con el maestro Rodrigo Alfonso ${ }^{42}$ y atribuyéndole otras obras, entre ellas un castillo en el Alentejo portugués —considerablemente alejado en el tiempo- ${ }^{43} \mathrm{y}$ la iglesia del monasterio de Guadalupe ${ }^{44}$, aspecto éste que se ha visto rodeado de una gran confusión (fig. 2).

En efecto, el nombre del maestro que edificó este templo ha sido siempre objeto de polémica. Si LLaguno lo adjudicaba a Juan Alfonso, basándose en el epitafio de su lápida sepulcral, la transcripción que del mismo nos ofrecen los Padres I. Acemel y G. Rubio omite el Juan, de manera que sólo contamos con el nombre o apellido Alfonso del supuesto maestro mayor de esta iglesia ${ }^{45}$. No obstante, el mismo Padre Germán Rubio nos aporta años después una información adicional, sumamente interesante. Al preguntarse por la identidad personal de este famoso maestro menciona un «Juan Alfonso, pedrero, maestro mayor de esta iglesia», que, según él, citan los documentos guadalupenses, y en concreto un Libro de Sepulturas del siglo

pintor, Juan Alfonso carpintero, Juan Alfonso albañil, e incluso otros dos pedreros, con la consecuente dificultad de identidad; así, desde 1399 se menciona un Juan Alfonso de Consuegra, pedrero (A.C.T., O.F. 86. Capilla de San Blas, fols. 48 r., 97 v.), que no es el mismo que nuestro Juan Alfonso, hijo del maestro Fernando Alfonso. Ambos, y aún otro más, Juan Alfonso, «hijo de Juan Alfonso el sellero» y criado del maestro Alvar Martínez, aparecerán juntos más adelante, en 1418 (O.F. 761, f. 66 v.), 1428 (O.F. 766, f. 193 r., y 194 v.), 1429 (O.F. 767, fols. 172 r., 182 r., 187 r.) y 1431 (O.F. 768 , f. 175 v.). Aunque normalmente el apelativo «el moço» nos permite distinguir a nuestro cantero, en ocasiones la identificación se ve dificultada por la utilización de expresiones confusas, como cuando se habla de «Johan Alfonso el moço, criado de Alvar Martínez maestro» (O.F. 766 (1428), f. 193 r.). ¿De quién se trata? ¿se refiere al hijo del maestro Fernando Alfonso, o al de Juan Alfonso el sellero? En este caso concreto pienso que se está hablando del segundo, puesto que previamente se había relacionado ya la talla entregada por el primero; otras veces, sin embargo, sería muy difícil afirmar nada al respecto.

41 J.A. CEÁn BermúdeZ, Diccionario, op. cit., t I, p. 17.

42 "Tenían un mismo patronímico y vivían en la misma época, de que se puede inferir eran hermanos «, y añade Ceán: «también pudieran ser padre e hijo, y esto parece ser lo más verosímil, pues hasta que muere el primero no asoma el segundo con sus obras» (LlaGuno, Noticias, op. cit., t. I. ver cap XII: «Juan Alfonso, Rodrigo Alfonso», pp. 74 y 83), afirmación absolutamente errónea, puesto que, muy al contrario, la figura de Rodrigo Alfonso aparece mucho antes que la de Juan Alfonso, siendo aquél coetáneo de Fernando Alfonso y este último el verdadero padre de Juan Alfonso.

${ }^{43}$ Ibidem., Idem., pp. 76-77: «..Pero esto no obsta a que el mismo Alfonso comenzase a disponer la construcción del castillo de Mouraon en el Alentejo el año siguiente de 1343, según una inscripción que se halla sobre la puerta interior del mismo castillo, pues acostumbran los grandes profesores trazar y dirigir obras de consideración a un mismo tiempo en pueblos y países distantes entre si».

${ }_{44}$ Ibidem., Idem., t. I, p. 75: «Juan Alfonso edificó la iglesia del monasterio de Guadalupe, empezándola poco después del año 1389, en que se dio aquel santuario a los monjes de San Gerónimo y duró la obra trece años... Murió y está enterrado allí este arquitecto, como parece de su lápida sepulcral con este epitafio: "Aqui yace Juan Alfonso, maestro/que fizo esta iglesia"». Ceán, en cambio, retrotrae la participación de Juan Alfonso en Guadalupe hasta el año 1342: "...se infiere de esta narración (se refiere al P. Sigüenza) que no se empezó a construir aquella iglesia poco después del año 1389, sino mucho antes... Es muy creíble que Juan Alfonso, el que está enterrado en la capilla de Santa Ana de este monasterio, haya trazado y construido todas las obras arriba dichas, emprendidas por el prior Toribio Fernández de Mena y comenzadas el año de 1342, después de la batalla de Tarifa» (Ibidem., Idem., n. 2, pp. 75-78).

${ }^{45}$ Esta transcripción se realiza a partir de una copia del siglo xviII sobre un azulejo, dispuesto en el muro de la capilla de Santa Ana, que dice lo siguiente: «Hic jacet Alfonso, maestro maior que fizo esta iglesia» (I. ACEMEL, y G. RuBio, Guía ilustrada del monasterio de Nuestra Señora de Guadalupe, Sevilla 1912, p. 50). La ambigüedad del epígrafe con respecto al nombre del maestro que edificó el templo ha dado lugar a que algunos especulen sobre su identidad, adjudicándolo a uno u otro de los miembros de la familia Alfonso, cuando no sugiriendo que los distintos Alfonsos mencionados en la documentación de Toledo y Guadalupe en estos años fuesen en realidad la misma persona. Así, J. R. MéLIDA, Provincia de Cáceres, «Catálogo Monumental de España», Madrid 1914-16, t. II, p. 133, duda entre Fernando Alfonso y su hijo Juan: «Es lástima que la copia del epitafio en el azulejo no nos haya conservado la fecha del sepelio, si la antigua lápida la tenía, pues de este modo podría aclararse un punto litigioso que la inscripción contiene, pues no sabemos en rigor qué maestro Alfonso es éste. Hubo un antiguo maestro Ferrand Alfonso cuyo hijo, Juan Alfonso, trabajó como escultor en el adorno de la fachada de la catedral de Toledo en 1418». Por su parte, L. ToRres BALBÁs (Arquitectura gótica, op. cit., p. 170) señaló que el maestro de Guadalupe enterrado en la capilla de Santa Ana bien podía ser el Ferrand Alfonso que en 1383 era maestro mayor de la catedral de Toledo, o el Rodrigo Alfonso que lo fue tiempo después, «en caso de no ser los dos una misma persona». Más conflictiva resulta aún la opinión de E. TORMO (El monasterio de Guadalupe y los cuadros de Zurbarán, Madrid 1906, p. 22), que ofreció una interpretación muy distinta del epígrafe, al identificar al maestro en él mencionado con el Alfonso que hizo la capilla, llamado Alonso de Plasencia, basándose en que se sabe que en 1507 era «maestro mayor de la obra de esta Santa Casa». 


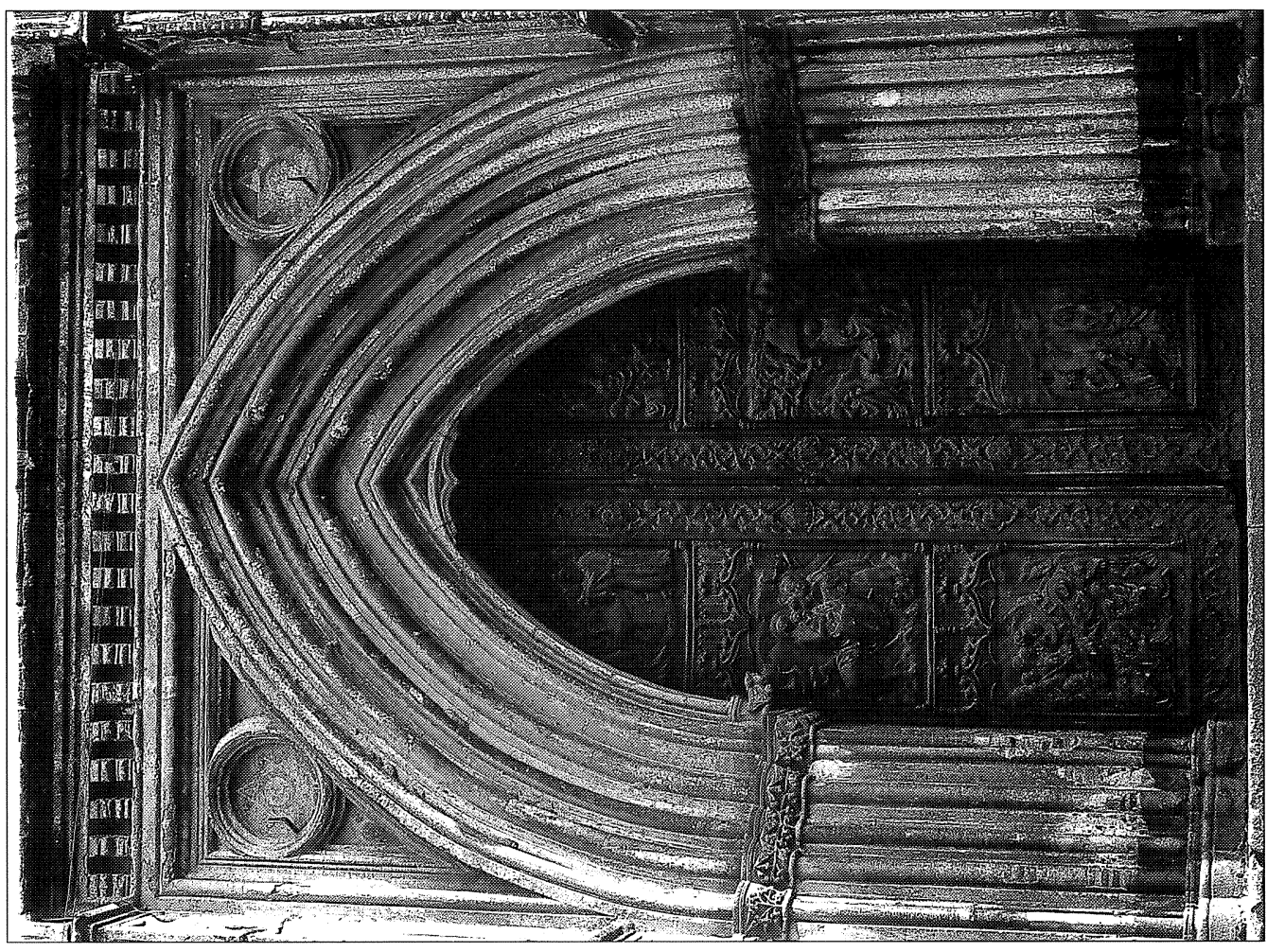

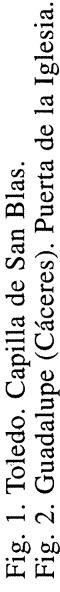

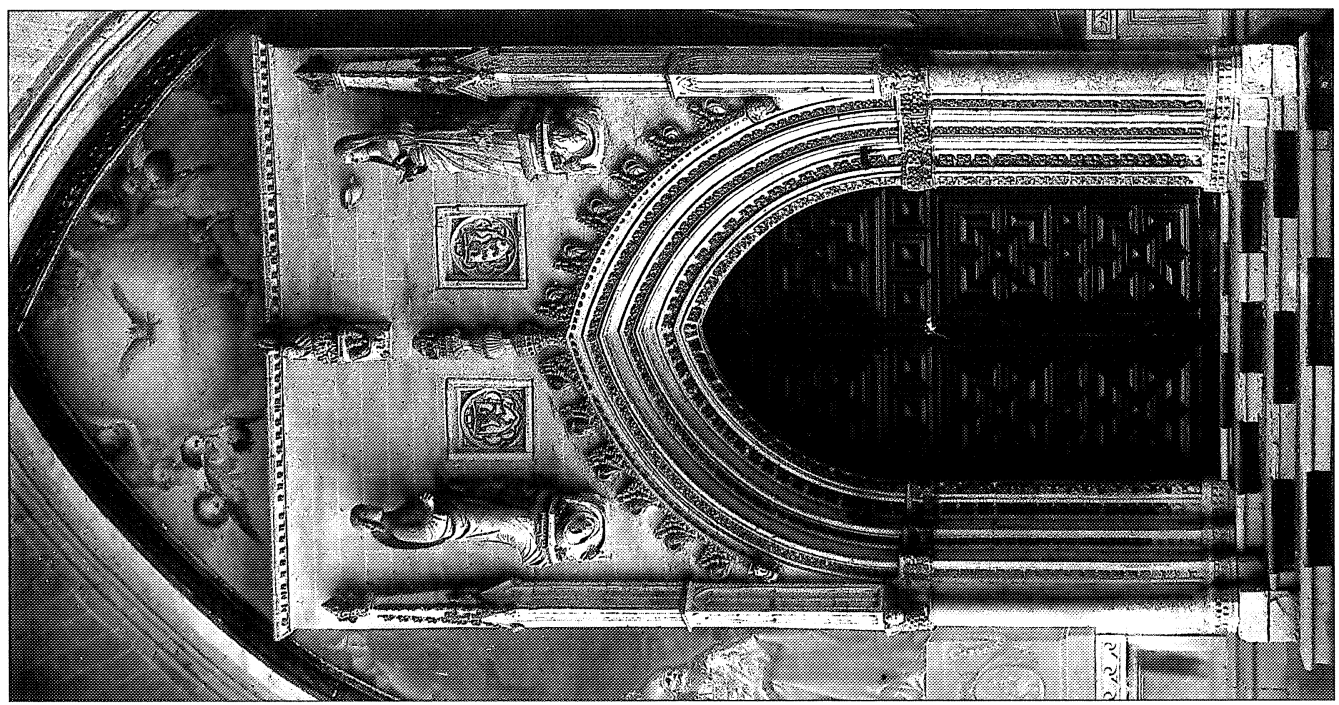


$\mathrm{XVI}^{46}$. Pero además, señala el testimonio de un nieto del artista - Gonzalo Gómez- que en 1509 declaró que su madre «era hija del maestro que hizo esta iglesia que se llamaba Pero Alonso», afirmación que, por otra parte, corrobora la abreviatura $\mathrm{P}^{\circ}$ que puede leerse en la tercera columna, contando desde el presbiterio inferior, a la entrada de la capilla mayor. El P. Germán concluye que ambas personas, Pedro y Juan Alfonso, serían en realidad una sóla, basándose en la coincidencia de oficios (ambos eran pedreros) y en la suposición de que los dos llevaron el apellido común Fernández, que después adoptaron sus herederos, convirtiéndolo por eufonía en Hernández ${ }^{47}$.

Creo por el contrario, de acuerdo con la información que se ha venido manejando - y en esto coincido con Almudena Sánchez-Palencia— ${ }^{48}$, que en ningún modo pueden identificarse ambos nombres con un único maestro, sino que responden a dos identidades distintas, aunque muy posiblemente emparentadas (fig. 3). Señalaba al principio que en 1383 trabajaban en la catedral de Toledo los hermanos Fernando Alfonso «el mozo» y Pedro Alfonso, seguramente hijos del pedrero Fernando Alfonso - o quizá de Diego Alfonso- y que aquél era, a su vez, padre del famoso Juan Alfonso «el mozo», que desde 1399 forma parte también de las cuadrillas de artífices al servicio de la catedral. Por tanto, de admitirse que los dos primeros son hijos del citado maestro Fernando Alfonso, como parece probable, tendríamos a los hermanos Juan Alfonso «el mozo» y Pedro Alfonso colaborando en la fábrica del monasterio extreme$\tilde{n}^{49}{ }^{4}$, con las oportunas reservas que la enorme frecuencia del patronímico Alfonso en estos años y la ausencia de fechas ciertas con respecto a la participación de Juan en la iglesia de Guadalupe nos obliga a adoptar ${ }^{50}$.

Ciertamente, del primero de estos dos maestros, Juan, no sabemos más que su ya referida mención en el Libro de Sepulturas del siglo xvi, sin que conste, sin embargo, la fecha del óbito, de manera que es difícil asegurar si cronológicamente es posible la identificación con el de Toledo. De Pedro Alfonso sabemos que era vecino de la Puebla de Guadalupe, donde formó su familia y tuvo al menos dos hijos - uno clérigo, llamado una vez más Juan Alfonso, y otro, el maestro de obras que sucedió a su padre en el oficio: Gonzalo Hernández- y que en 1424, 1427 y 1429 aparece como testigo en diversos documentos del monasterio, lo que indica que su muerte hubo de producirse después del 10 de septiembre de este año, 1429, última referencia que tenemos del mismo ${ }^{51}$. En todo caso, lo que resulta imposible es separar la parte de responsabilidad que toca a cada uno en la ejecución del magnífico edificio y aclarar cuál de ellos - si es que participaron los dos - fue realmente el maestro mayor, o si uno sucedió a otro en el cargo, o bien si pudieron compartirlo, al menos durante cierto periodo de tiempo. Es interesante, sin embargo, que no volvamos a encontrar a Pedro Alfonso en Toledo después de 1418 , lo que unido a su asentamiento definitivo en Guadalupe, donde fija su residencia (en una fecha imprecisa entre 1418 y 1424), parece indicar una vinculación más clara, o al menos más temprana, con la fábrica del templo jerónimo que la de su hermano, que como se ha visto plantea todas las dudas. Desde luego, mientras la documentación no arroje alguna luz sobre este

\footnotetext{
${ }^{46}$ G. Rubio, Historia de Nuestra Señora de Guadalupe, Barcelona 1926, pp. 363-365. Quizá este Libro de Sepulturas del siglo XVI fuera la fuente en que bebiera Llaguno para atribuir a Juan Alfonso la fábrica de este edificio, atribución de la que después se haría eco buena parte de la historiografía artística sobre el templo. A. SÁNCHEZ-PALENCIA, «La escuela toledana..», op. cit., p. 106, da a entender no haber hallado el mencionado libro, ni, por tanto, la mención a Juan Alfonso, por lo que no hay forma de precisar el contexto en que aparece ni de identificar su personalidad.

${ }^{47}$ Ibidem., Idem., p. 364.

48 «La escuela toledana...», op. cit., p. 105.

49 A. SÁnChez-PALEncia, «La escuela toledana...», op. cit., p. 106, piensa que este Pedro Alfonso es en realidad hijo de Diego Alfonso, basándose en el apellido de su mujer, Francisca Fernández, que luego adoptaría Pedro Alonso Fernández.

${ }^{50}$ Recordemos que en los propios talleres de Toledo, sin ir más lejos, trabajaban coetáneamente otros dos maestros del mismo nombre: Juan Alfonso «de Consuegra» y Juan Alfonso «hijo de Juan Alfonso el sellero».

${ }^{51}$ G. Rubio, Historia, op.cit, pp. 364-365.
} 


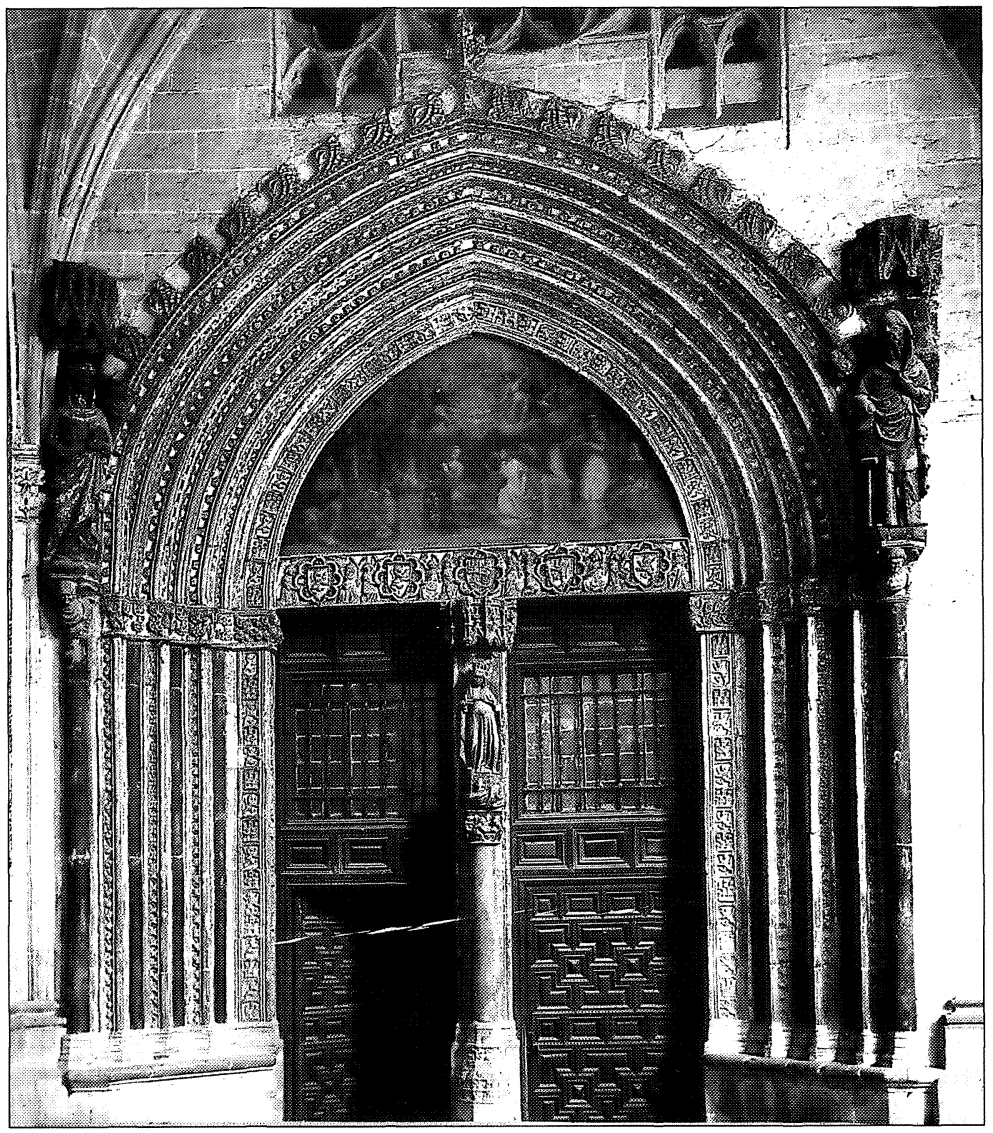

Fig. 3. Toledo. Capilla de Santa Catalina.

asunto no podemos identificar la obra material del personaje que ahora nos interesa - Juan Alfonso-, de manera que hemos de acudir a otros lugares donde ésta es bien concocida; me refiero fundamentalmente a Toledo.

Sin embargo, no queremos dirigir nuestra atención hacia la capital metropolitana sin antes, aunque sea tan sólo indicar qué parte de la fábrica del monasterio corresponde al periodo cronológico en que pudo producirse la intervención de estos dos maestros, o con más seguridad de Pedro Alfonso- periodo que en parte coincidiría con la etapa en que fue regido por su primer prior regular, fray Fernando Yáñez (1389-1412) ${ }^{52}$. Un estudio reciente al respecto es el que debemos al profesor Ruiz Hernando que, si bien no presta gran atención al problema del arquitecto - simplemente recoge la afirmación de LLaguno, que lo atribuía a Juan Alfonso, y la de Torres Balbás que, recordémoslo, dudaba entre Fernando y Rodrigo Alfonso-, nos informa en cambio de lo que, en su opinión, se construyó durante el primer priorato del convento

\footnotetext{
52 En 1993 salió a la luz una obra de conjunto que ponía al día todo lo referente a la historia, vida religiosa, arquitectura y arte en el monasterio extremeño, haciéndose eco y sometiendo a crítica histórica gran cantidad de trabajos previos, de características muy dispares y no siempre demasiado rigurosos: S. García Rodríguez (O.F.M.) (coordinador) y otros, Guadalupe: siete siglos de fe y cultura, Guadalupe 1993. El estudio arquitectónico, que ahora nos interesa, corre a cargo de T. BERNAL GARCía, que ofrece un panorama general («El monasterio de Guadalupe: visión arquitectónica conjunta», pp. 245259) y J. A. Ruiz Hernando, que se centra en las construcciones de los siglos xiv y xv —las más controvertidas en lo que a sucesión de fases constructivas se refiere-, mostrando especial interés por delimitar lo que corresponde a la etapa jerónima y cómo se resuelve durante la misma la adaptación de las edificaciones ya existentes a las necesidades de la Orden («El monasterio de Nuestra Señora de Guadalupe: su arquitectura antigua. Siglos XIV y XV», pp. 260-285).
} 
jerónimo ${ }^{53}$. En líneas generales, resumiendo sus conclusiones, a éste sólo debió corresponder el abovedamiento del templo y la adecuación del mismo a las exigencias litúrgicas de la Regla. Así, mantuvo la iglesia de tres naves levantada anteriormente - lo que, por otro lado, explica el porqué de una tipología arquitectónica que no era la preferida por los jerónimos-, convirtió la antigua capilla de San Martín, a los pies del templo, en sala capitular, construyendo sobre ella un coro elevado, y ordenó la construcción del llamado claustro «mudéjar», junto con buena parte de sus capillas y dependencias, así como sus famosas fuentes de autoría conocida (Juan Francés y fray Juan de Sevilla). En definitiva, el maestro Alfonso, cualquiera que fuese, sino ambos, pudo hacerse cargo de la cubrición de la iglesia, la reestructuración de su zona occidental y la ordenación de un claustro de gusto islamizante. Quiero insistir, sin embargo, en las dificultades para precisar lo que corresponde a cada uno de los posibles maestros; como mucho, se pueden entrever los rasgos generales de su estilo, en consonancia con los esquemas tradicionales, característicos de la arquitectura castellana del trescientos, pero mediatizado también por las construcciones ya existentes y las exigencias de los encargantes, cuando no enmascarado por intervenciones posteriores.

Acudimos, ahora sí, a Toledo, donde a pesar de las lagunas podemos seguir a nuestro maestro muy de cerca. La actividad de Juan Alfonso en la catedral metropolitana se documenta de forma continua desde el mes de enero de 1399 hasta 1400, trabajando, bajo la dirección del maestro Rodrigo Alfonso, en la capilla de San Blas que el arzobispo Tenorio mandó construir en el claustro para su enterramiento. En enero de 1399 desbasta piedra en la cantera junto con el maestro y los pedreros Alfonso Fernández, Juan Díaz y el que años después sería maestro mayor de la catedral, Alvar Martínez. El administrador, Fernando Gómez, le entrega cada día nueve maravedís; seis para él y tres para el peón que le acompaña. El último día de dicho mes estuvo haciendo los quicios de los revestuarios para poner las puertas, lo que hará el primero de febrero. El resto del año trabaja en los muros y, fundamentalmente, en la portada de la capilla. Así, en el mes de marzo él y el maestro empiezan la ventana que sale al corral. En la obra de la portada - que se prolonga a lo largo de este año y el siguiente- colabora con Antón Rodríguez, Alfonso Rodríguez, Diego López, Pedro Martínez «el viejo», Antón Fernández, Ferrand Sánchez, García Martínez, Juan Alfonso de Consuegra, Alfonso Ruiz, Alvar González, Gil Gómez, Pedro, criado del maestro, Gonzalo Yáñez Chamorro, Diego Martínez, Ferrand Pérez y Ferrand González, además de los antes citados. Todos ellos forman parte de lo que Almudena Sánchez-Palencia ha llamado la «escuela toledana» que, dirigida por el maestro mayor Rodrigo Alfonso, participaría en la mayoría de las obras auspiciadas por Pedro Tenorio y ejercería su influencia en muchas otras. Ello explicaría, por otra parte, la unidad estilística que manifiesta la portada, a pesar de las muchas manos que la realizan ${ }^{54}$.

\footnotetext{
53 J. A. Ruiz Hernando, «El monasterio de Nuestra Señora de Guadalupe....», op. cit. La conclusión del autor es que, efectivamente, existieron las tres fases que indican cronistas de la Orden e historiadores modernos del monasterio. Los problemas surgen a la hora de deslindar lo que se atribuye a cada una de ellas. Si en las fuentes indicadas, llevados por un lógico amor a su Orden jerónima, los autores atribuyen casi la totalidad de su monasterio al primer prior regular - el citado Fernando Yáñez - un estudio concienzudo le lleva a replantear la cuestión. Así, una ermita muy sencilla, construida de piedra y madera, habría sido la primera construcción, sustituida por orden de Alfonso XI por otra de ladrillo, de la que persisten los restos del ábside. Poco tiempo después de haber levantado el rey esta iglesia, fue nuevamente renovada por completo. En la que subsiste actualmente se trabajó durante toda la segunda mitad del siglo xiv. Esta última renovación debió ser iniciada, al menos, en tiempos del prior secular Toribio Fernández de Mena (1348-1368) y proseguidas después por Diego Fernández (1368-1379), de modo que cuando llegan los jerónimos, a fin de siglo, el templo estaba en obras. Durante este tiempo se habían levantado las murallas con sus torres, albergues para peregrinos, casas para capellanes, y buena parte del templo — de tres naves e igual longitud que el actual-, casi tan sólo a falta de su cubrición, que estaba por hacer a la llegada de fray Fernando.

${ }^{54} \mathrm{La}$ autora ha individualizado la labor de cada uno de ellos. Juan Alfonso, a quien ahora se denomina «el mozo», talla «una coz de quiçio de abajo de la portada bovado y entallado»; una cuerda del "sobrearco perpeañado», de media cuerda y medio palmo; una piedra del revestimiento del sobrearco tercero, de media cuerda y cuatro dedos; setenta «boças de vid,
} 
Desde entonces un gran vacío documental, que se prolonga durante casi las dos primeras décadas del siglo xv, nos impide seguir la trayectoria del maestro. En adelante sólo lo encontramos en los años 1418, 1427, 1428, 1429 y 1431; entre 1418 y 1427 no nos consta su presencia en Toledo ${ }^{55}$, aunque hemos de tener en cuenta que, desgraciadamente, no conservamos tampoco los libros de Obra para el periodo 1418-1424. Sabemos, además, que durante este tiempo contaba con la colaboración de un criado, Diego Fernández ${ }^{56}$.

En la primera de las fechas citadas talla diversas piezas destinadas a la puerta del Perdón, donde por entonces se trabajaba, y labra sillares para el solado del templo que se había comenzado. Desde este momento no cabe duda alguna sobre su filiación, reiterándose que se trata del «fijo del maestro Ferrand Alfonso» ${ }^{57}$. El 21 de junio de 1427 se le paga por la entrega de material para los remates de los botareles de la cabecera, así como por siete piedras para la torre del Reloj, cuatro con las armas del rey y tres con las del arzobispo don Juan ${ }^{58}$.

El 4 de marzo de 1428 entrega piedra blanca para la torre de las Campanas, así como ocho piezas de sillar, nuevamente con las armas del rey y del arzobispo, para la torre del Reloj. Más adelante, el 4 de junio del mismo año, una nueva remesa de material con destino a la torre de las Campanas ${ }^{59}$. Esta vez se le identifica como «Juan Alfonso el mozo, fijo de Ferrand Alfonso, maestro de la obra». Sabemos por ello que se trata de la misma persona que desde enero de 1399 está trabajando en la capilla de San Blas, pues también entonces recibía el apelativo «el mozo» que en ambas ocasiones nos permite distinguirlo de Juan Alfonso de Consuegra y en 1429, además, de Juan Alfonso, «fijo de Juan Alfonso el sellero» y criado del maestro Alvar Martínez, ambos pedreros.

En 1429 (27 de octubre) se le valoran siete piedras blancas del Regachuelo con las armas del arzobispo don Juan y ocho con las del tesorero, cuatro para la torre de Campanas y otras tantas para la del Reloj, así como dos capiteles, cuatro cimacios etc. ${ }^{60}$.

Finalmente, el 13 de marzo de 1431 se le tasó en ochenta maravedís una piedra blanca de Regachuelo con las armas del tesorero para la torre de las Campanas, «esquadrada e bovada e entallada» ${ }^{61}$, y se le abonan un total de 1875 maravedís y 5 dineros por la entrega de piezas diversas para dicha torre - ahora de piedra berroqueña, procedente de la cantera de Guadaxaras- el 31 de marzo y el 8 de noviembre del mismo año ${ }^{62}$. En los años que transcurren entre las fechas límite mencionadas - 1399 y 1431 - su maestrazgo se extendió a otras canterías, para entonces en plena actividad. Es el caso de la fábrica de la catedral de Cuenca.

Por fortuna, la escasísima información documental que poseemos para los primeros años del siglo Xv nos lo muestra indudablemente vinculado, desde fechas muy tempranas, a los talleres de la catedral de Cuenca, que a la sazón administraba el canónigo obrero Pedro Martínez de Chillarón, durante el episcopado de Juan Cabeza de Vaca (1396-1408). Sin embargo, su

\footnotetext{
de espino y de roble»; treinta y cinco «boças de arabie»; una «chapa de fillola» y un escudo de las armas del arzobispo. Importa toda su talla cuatrocientos noventa y cinco maravedís y dos dineros (A. SÁnCHEZ-PALENCIA, «La capilla del Arzobispo...», op. cit. p. 35; Fundaciones del arzobispo, op. cit. p. 34).

55 Sólo en 1424 (24 de mayo) se documenta un Alfonso Fernández, criado de Juan Alfonso; pero este último no es nuestro personaje, sino el Juan Alfonso de Consuegra que constatábamos ya en 1418, como indica otra referencia más explícita unos meses después (4 de septiembre de 1424). A.C.T., O.F. 762 (1424), f. 31 r. y 162 v.

56 «Diego Ferrández, pedrero, criado de Juan Alfonso el moço» ó «Diego Ferrández, criado de Juan Alfonso, fijo del maestro»: A.C.T., O.F. 766 (1428), f.196 r.; 767 (1429), fols. 82 r.; 183 r. Otro Diego Fernández, "fijo de Alfonso Ferrández aparejador», aparece trabajando en las mismas fechas; ignoramos si se trata de la misma persona.

57 A.C.T., O.F. 761 (1418), fols. 81 r., 123 v., 152 r./v. Véase en apéndice, doc. $n .^{\circ} 2$.

58 A.C.T., O.F. 765 (1427), f. 167 v. Apéndice, doc. n. ${ }^{\circ} 2$.

59 A.C.T., O.F. 766 (1428), f. 181 v. Apéndice, doc. n. ${ }^{\circ} 2$.

60 A.C.T., O.F. 767. (1429). f. 172 r. Apéndice, doc. n. ${ }^{\circ}$ 2. Sumaba el total de su trabajo tres mil doscientos cincuenta y seis maravedís y dos dineros.

61 A.C.T., O.F. 768 (1431), f. 153 v. Apéndice, doc. n. ${ }^{\circ} 2$.

62 A.C.T., O.F. 768 (1431), f.191 r. Apéndice, doc. n. ${ }^{\circ} 2$.
} 
posterior historia constructiva no nos ha permitido conocer nada de lo que el pedrero toledano pudo trazar o «tallar» para este edificio, haciendo imposible, por tanto, cualquier análisis comparativo.

Gracias a una pequeña serie de cuadernillos sueltos — por otra parte muy fragmentariosque el Archivo capitular conquense ha podido conservar de lo que hubieron de ser sus primeros libros de fábrica, sabemos que el cabildo contrató con él los «pilaretes» del claustro en 1407. Las anotaciones no son muy explícitas, pero al menos nos informan de su protagonismo en la construcción del claustro gótico, tristemente desaparecido aunque, eso sí, remplazado por otro bellísimo del siglo xvi. Asimismo, y en las mismas fechas, se ocupa el pedrero toledano del solado de la iglesia de Cuenca, gradas del claustro y alguna que otra obra de menor envergadura. Así, un registro en el libro de fábrica correspondiente a este año nos informa que el dia 31 de octubre, Pedro Martínez de Chillarón contrata con el pedrero Juan Alfonso de Toledo doce palmos de piedra para los pilaretes del claustro, así como el solado de la puerta de la Miel: «Iten, este día fise convenençia con Johan Alfonso de Toledo, pedrero, por doçe palmos de piedra para los pilaretes de la claustra, por que solare e pavimentase la puerta que diçen de la miel, todo a su costa, por preçio de mill maravedís en blancas. E destos mill maravedís le di en miércoles, dos días del mes de novienbre, para las açémilas que truxieron la piedra sesenta maravedís» ${ }^{63}$. En los días sucesivos, y aún en los primeros meses del año siguiente, se le continúan haciendo pagos por este concepto ${ }^{64}$. Finalmente, el 5 de marzo de 1408 el obrero hace cuenta con Juan Alfonso de la cuantía de la obra realizada, concluyendo que ésta montaba un total de dos mil ciento ochenta y cinco maravedís, de los cuales el cantero había recibido ya mil cuatrocientos cincuenta, debiéndosele por tanto lo que restaba: «Iten más, fise cuenta con Johan Alfonso pedrero, así de los pilares mayores e menores de la claustra como de las varas de piedra que puso en el suelo de la eglesia, e fallóse que hasta oy día lunes que puso en los pilares mayores onçe palmos, cada uno a treynta e çinco maravedís, e en los pilares menores veynte palmos, cada uno palmo veynte $e$ çinco maravedís, e en el suelo de la eglesia çient varas, cada una vara a treçe maravedís, lo qual todo suso dicho montó dos mill çiento e ochenta e çinco, de los quales tenía pagados mill quatroçientos e çinquaenta e él ovo de aver seteçientos e treynta e çinco maravedís. Los quales le pagué luego en dineros contantes» ${ }^{65}$.

A partir de este momento se interrumpe la información de que disponemos. Desde esta fecha una gran laguna en la serie de fábrica nos impide trazar una línea continua en la actividad de este cantero. No obstante, afortunadamente estamos en condiciones de afirmar que de algún modo siguió vinculado al cabildo conquense y a la Obra y Fábrica de su catedral, puesto que en 1420 y 1421 — según se recoge en los libros de actas capitulares correspondientes a estos años- firma sendos contratos con aquél ${ }^{66}$. Para entonces era Juan Alfonso de Muriel,

\footnotetext{
${ }^{63}$ A.C.C. Fábrica, 8., f. 29 r.

${ }^{64}$ Ciento cuarenta maravedís, el 5 de noviembre; cien el 10 de dicho mes y otros tantos el mismo día por los cuatro cahíces de cal que envió Diego Martínez de Alvendea; el 19, doscientos maravedís; un florín más el 2 de diciembre, en precio de cincuenta y dos maravedís el florín; el día 3 de diciembre recibirá cien maravedís; tres florines el martes día 6 (en total ciento cincuenta y seis maravedís); el miércoles 14, noventa y dos maravedís en blancas "para conplimiento del pago de los dos mill maravedís de las gradas e del pilar de la claustra»; el domingo 18 de diciembre, doscientos maravedís; el jueves 22, cien; el viernes 30, cincuenta; y otros cien más el dia 31 de diciembre. Estos pagos se prolongan en los primeros meses del año siguiente - 1408-: cincuenta maravedís, el 3 de enero; cien, el dia 5; ciento cincuenta, el 22; doscientos cincuenta, el primero de febrero; cien, el dia 11; doscientos el 18 y ciento cincuenta el 24 de este mes (A.C.C. Fábrica, 8, ff. 29 r. a 33 r.; sign. II.9, fols. 10 v./11 r.).

65 A.C.C. Fábrica, 9, f. 11 v.

${ }^{66}$ Con anterioridd a estas fechas, en 1415 y 1416, se cita a un Juan Alfonso, "conpannero en la eglesia de Cuenca, fijo de maestre Alfonso», en relación con las rentas que se le debían de los frutos pertenecientes a su beneficio de Santa María de Alarcón (A.C.C. Sign. A.2, fols. 71 r. y 120 r). Pudiera tratarse de la misma persona cuya trayectoria tratamos de seguir
} 
abad de la Sey, bachiller en decretos y vicario general, el administrador de la Obra de la iglesia de Cuenca.

El 18 de octubre de 1420 el deán y el cabildo «tomaron por oficial cantero a Juan Alfonso, fijo de Ferrant Alfonso», expresión que además permite confirmar - junto con el hecho de que en alguna ocasión se indique expresamente su origen toledano- que se trata del mismo Juan Alfonso «el mozo», hijo de Fernando Alfonso, que en 1399-1400 trabajaba en la capilla del arzobispo Tenorio, especialmente en su portada, que en 1418 había colaborado en la decoración de la portada del Perdón y que posteriormente, entre 1427 y 1431, seguiría aportando su trabajo para los botareles de la cabecera, así como para las torres de las Campanas y del Reloj en la catedral metropolitana. Entre los acuerdos adoptados por el cabildo conquense en la fecha citada encontramos el siguiente:

\section{Contrato del cabildo con Juan Alfonso cantero.}

Viernes, diez e ocho días de octubre, anno domini MCCCCXX annos, los sennores deán e cabilldo tomaron por su oficial cantero a Juan Alfonso, fijo de Ferrant Alfonso, de mientre lo oviere menester para las obras de la eglesia, al qual otorgaron que de la su mesa aya cada día por oficial hun maravedí. Enpero que quando por los dichos sennores o por alguno dellos fuere llamado para obras de la eglesia e cabilldo, sea tenido luego yr a trabajar de los ofiçios que sabe, e cada día de trabajo den dose maravedís e quatro coronados, otorgándole el privillegio e libertad de la dicha eglesia de mientre sirviere el dicho offiçio, e cada que fuere llamado e non fuere a faser obra, quel tal pueda tomar otro maestro que la faga a pro de la eglesia e a danno del dicho Juan Alfonso, etc. $\left(. . .{ }^{67}\right.$.

Juan Alfonso recibiría, pues, un maravedí diario en su calidad de oficial y se le obligaba a acudir a la obra en caso de que así le fuera requerido, asignándosele además un jornal de doce maravedís y cuatro coronados por día de trabajo; en caso contario, el cabildo se reservaba el derecho de tomar otro maestro, con el consecuente perjuicio económico que de ello pudiera derivar para el primero. De esta manera, la Iglesia de Cuenca se cubría las espaldas ante sus posibles ausencias (tal vez motivadas por desplazamientos a Toledo, Guadalupe, Talavera...) y el consiguiente peligro de que no se presentase a tiempo cuando fuera menester, circunstancia ésta que se intenta evitar. Por lo demás, el hecho de que se indique expresamente su obligación de acudir a trabajar «de los oficios que sabe» viene a corroborar que la formación de estos artífices era multidisciplinar y que, con fecuencia, una misma persona podía estar habilitada para el trabajo de la piedra, la madera o el yeso, e incluso para el ejercicio de la pintura.

El libro de las rentas de 1421 viene a refrendar esta información y aporta algún otro dato. En efecto, entre los oficiales del cabildo el escribano incluyó al «maestro de las obras de las posesiones del refitor, Johan Alfonso, fijo de Ferrand Alfonso», con la cantidad que le correspondía por el oficio de su maestría: 366 maravedís. De éstos, recibe 50 el 27 de febrero de ese año; otros 250 , de lo que el maestro debía en concepto de renta por las casas que tenía alquiladas en las Peñuelas de San Esteban; los 66 restantes se los entrega el racionero Miguel Martínez, que actúa como procurador del canónigo y refitolero Pedro Carrillo. Juan Alfonso otorga carta de pago por el salario del año indicado el 24 de octubre de 1424 y como no sabe

\footnotetext{
aquí; en este caso ese «maestre Alfonso», su padre, no sería otro que el maestro Fernando Alfonso. De ser así, se demostraría la continuidad de Juan Alfonso en el taller y su vinculación con el cabildo como «compañero» (medio racionero) del mismo. No obstante, la ausencia en este caso de referencia alguna a su actividad como cantero nos obliga a mantener ciertas reservas al respecto. Con mayor motivo, cuando tenemos constancia de un maestre Alfonso, físico, entre los oficiales del cabildo en 1396 (A.C.C. Mesa Capitular. Libros de Rentas, 1396, s.f.), que bien podría identificarse con el padre de ese otro Juan Alfonso, compañero en las fechas arriba indicadas. Por lo demás, tampoco las referencias documentales posteriores al maestro Juan Alfonso expresan nada que permita inferir que se convirtiera en medio racionero en la iglesia de Cuenca.

${ }^{67}$ A.C.C. Secretaría. Sign. A.3., f. 111 v.
} 
firmar pide al racionero Miguel Fernández y a Ruy Sánchez, compañero, que lo hagan en su nombre ${ }^{68}$.

El contrato de octubre de 1420 se reiteraba poco más de un año después. El 2 de noviembre de 1421 el canónigo Juan Alfonso, abad de la Sey y a la sazón obrero, en nombre de todo el capítulo tomaba "por maestro obrero para la dicha eglesia a Juan Alfonso, cantero, fijo de Ferrand Alfonso» ${ }^{69}$ :

Obra y Juan Alfonso, maestro de ella.

Este día el abat de la sey Juan Alfonso, canónigo, tomó por maestro obrero para la dicha glesia a Juan Alfonso, cantero, fijo de Ferrand Alfonso, el qual se obligó con todos sus bienes e prometió a buena fe, sin mal enganno, de aquí adelante fasta hun anno e dende cabo adelante, por el dicho ofiçio en tienpos devidos requirá todos los tejados de la dicha eglesia e ver onde se lloviere e por sí o por otro sobir a quitar las goteras, así de la dicha eglesia commo los palaçios del dicho sennor obispo, dándole al dicho obrero teja e madera e pertrecho para ello. $E$ esto fasiendo, el dicho abat, administrador de la dicha obra, obligó los bienes de ella de le dar e pagar por su trabajo e administraçión de aquí adelante por hun anno e cabo adelante tresientos maravedís e dos kafises de trigo. Otrosí el dicho obrero fiso avinimiento con el dicho Juan Alfonso que cada hun día que andudiere obrando en la obra de la dicha eglesia a retejar, o de nuevo obra faser en ella de aquí adelante, de le dar e pagar dose maravedís de jornal sin otra alguna pitança nin govierno, e obligó los bienes de la dicha obra de le dar el hun kafis de trigo luego e el otro cafis fasta Sant Juan de junio primero avenidero, e los tresientos maravedís por tercios de cada hun anno, e los jornales que ganare commo fuere obrando que así le vaya pagando, sopena de çinco maravedís por cada dia etc. Testigos (...).

En esta ocasión el maestro se comprometía a subsanar todos los desperfectos - fundamentalmente por filtraciones de agua- que pudieran sufrir el templo catedralicio y el palacio espiscopal, a cambio de trescientos maravedís y dos cahíces de trigo anuales «por su trabajo e administraçión». Otros doce maravedís, «sin alguna otra pitança», le serían entregados por cada día que él mismo trabajase en las canteras y talleres de la Obra o en el propio edificio, bien retejando, bien labrando o asentando en obras nuevas. Este jornal lo percibiría a medida que fuera trabajando, mientras que los trescientos maravedís del oficio de la maestría se repartirían — según sistema habitual - en tercios de año. Las condiciones, aunque expresadas de manera distinta, venían a ser, por tanto, muy similares a las establecidas en el contrato anterior. En cambio, sí es significativo que se indique ahora en qué consistía en lo fundamental la labor de este maestro- - «requirá todos los tejados de la dicha eglesia e ver onde se lloviere e por sí o por otro sobir a quitar las goteras..»-, centrada, sobre todo, en las obras de mantenimiento, conservación y reparaciones que fueran oportunas, especialmente en los tejados, lo que indica que en aquellos momentos la fábrica no mantenía una gran actividad y, salvo obras circunstanciales, aquéllas eran las tareas esenciales ${ }^{70}$.

Luego este Juan Alfonso, cantero, aparece como testigo en un compromiso, fechado en 13 de marzo de 1422, entre la obra, representada por su administrador — Juan Alfonso-, y Alfonso Martínez de Morejón, vecino de Palacios de Campos, que había contraído una deuda con la misma de doce florines de oro ${ }^{71}$. Esta será la última vez que tengamos constancia de su presencia en la cantería de Cuenca, aunque la carencia de los libros de fábrica correspondientes a este periodo cronológico nos impide afirmar nada al respecto ${ }^{72}$.

\footnotetext{
${ }^{68}$ A.C.C. Mesa Capitular. Libros de Rentas, 1421. s.f. Ver en apéndice, doc. n. ${ }^{\circ} 3$.

69 A.C.C. Secretaría, sign. A.3. f. 157 r.

${ }^{70}$ No contamos con mas información - ni de Fábrica ni de Actas Capitulares-, para estos años, que nos permita corroborar esta opinión, aunque sí sabemos de la importancia de los trabajos de reparación, mantenimiento y retejado en los años inmediatamente precedentes.

71 A.C.C. Secretaría. Actas Capitulares. Sign. A.3. f. 166 r.

72 Aunque en 1424 otorga carta de pago, no sabemos si durante este tiempo siguió trabajando para la Obra de Cuenca.
} 
En definitiva, la obra de la catedral conquense contó con la presencia activa de por lo menos dos miembros - Fernando Alfonso y Juan Alfonso- ${ }^{73}$ de una de las más complejas e influyentes familias de canteros en el territorio del antiguo Arzobispado, desde las últimas décadas del siglo xIV hasta bien avanzada la decimoquinta centuria; familia cuyo «hacer», aún arraigado en las fórmulas tradicionales, marcaría buena parte de la arquitectura auspiciada por el arzobispo Tenorio y sus inmediatos sucesores, así como la llevada a cabo en su radio de influencia.

\section{APÉNDICE DOCUMENTAL}

Doc. n. $^{0} 1$

Pagos a Ferrando Alfonso en concepto de jornales por su trabajo para la Obra de la catedral de Cuenca. (1405, lunes, 1 de junio)

Di a Ferrando Alfonso por su jornal, diez e seys maravedís.

(1405, martes, 2 de junio)

Mandé façer çinco almenas en el dicho corral. E di al dicho Ferrando Alfonso por su jornal deste día diez e seys maravedís.

A.C.C., II.7, f. $30 \mathrm{v}$.

(1407, lunes, 30 de mayo)

Lunes, XXX días del mes de mayo, fiçe començar de levantar la dicha pared (en el corral). Di a Ferrando Alfonso e a Lope Sánches por sus jornales, XXX maravedís.

A.C.C., II.8, ff. 22 v. y 22 bis r.

(Se les paga otros 30 maravedís de jornal el martes 31 de mayo y lo mismo el 1 de junio).

Doc. n. $^{\circ} 2$

Pagos a Juan Alfonso, por su trabajo para la Obra de Toledo (1418-1431)

(1418, mayo):

Alvar Gonçález e Alfonso Díaz e Ferrand Garçía e Johan Alfonso, pedreros, que asentaron este día piedra para el dicho asiento (de la Puerta del Perdón). XV maravedís a cada uno.

A.C.T., O.F. 761, f. $81 \mathrm{r}$.

(Talla que dió) «Johan Alfonso, fijo del maestro Ferrand Alfonso»

(1418, miércoles, 15 de junio)

Miércoles, quinçe días de junio, anno de MCCCCXVIII annos, dio el dicho Johan Alfonso, pedrero, la talla que se sigue. Primeramente dio un capitel del boçel para la puerta del Perdón, escuadrado e bovado e entallado, apreçiado en dosientos maravedís.

Dio más un somel del cunno escuadrado e bovado, que fase responso a amas partes de las mayores, apreçiado en quatroçientos quarenta maravedís.

Iten, dio más un quarto de un somel para la puerta del Perdón escuadrado e bovado, apreçiado en noventa maravedís.

Entalló más siete boças e bestiones para el entablamiento de la puerta del Perdón a diez y ocho maravedís cada una, que son çiento veynte e seys maravedís.

Iten, dio más dos cuerdas e media de syllares de Regachuelo a XVI la cuerda, que son quarenta maravedís.

Dio más de las losas de Regachuelo tres cuerdas e media a seys maravedís la cuerda, que son veynte e un maravedí.

(1418, lunes, 19 de septiembre)

Lunes, dies e nueve días de setienbre, anno de MCCCXVIII annos, dio el dicho Johan Alfonso, fijo del maestro Ferrand Alfonso, esta talla que se sigue. Primeramente dio un tabernáculo para las ymágenes de la puerta del Perdón escuadrado e bovado e entallado, apreçiado en seysçientos maravedís.

\footnotetext{
${ }^{73}$ No descartamos la posible participación de otros a los que el azar no habría tratado de la misma manera, teniendo en cuenta lo fragmentario de la documentación conservada. A este respecto, es importante señalar la presencia de un Rodrigo Alfonso, que se documenta en 1421 en relación con las obras de una de las posesiones del cabildo - los molinos de la Noguera-, aunque, en este caso, no parece tratarse de un cantero: «Item, a XXVII días de enero, mandó el sennor deán que dieran a Diego Sánchez Avarca e a Rodrigo Alfonso, maestros de façer yeso, çiento e veynte maravedís por dies cafiçes de yeso. E costó el cafiz a XII maravedís, que fue menester para reparar una pared que se cayó del molino de la Noguera»(A.C.C. Mesa Capitular. Libro de Rentas de 1421. s.f.).
} 
Iten dio más de sillares de Regachuelo siete cuerdas e un palmo, apreçiada la cuerda a dies e seys maravedís, que son ciento e diez e seys maravedís.

A.C.T., O.F. 761, f. 123 v.

(Obras dadas a destajo):

(1418, miércoles, 20 de_abril) . .

Miércoles, veynte días de abril, anno de MCCCCXVIII annos, este día dio e pagó Alfonso Martínez, raçionero de la eglesia de Toledo, a Johan Alfonso, fijo de Ferrant Alfonso, maestro que fue de la obra, e a Antón López, pedreros, dos mill e quatroçientos e sesenta maravedís que ovieron de aver para en cuenta de çiento e veynte e tres cuerdas de losas prietas de las de la cantera del Miraglo, que han de arrancar e desbastar e traer aquí a Toledo, a su costa e misión, e de labrar e polir para solar la eglesia, segúnd que está començada a façer e solar, a rasón de quarenta maravedís la cuerda, que montan a dicho presçio quatro mil e nueveçientos e veynte maravedís, e que las den fechas e labradas, como dicho es, fasta en fin del mes de mayo primero que viene deste dicho anno. E que los otros maravedís fincables que gelos paguen, la meytad dellos arrancada la piedra e la otra meytad acabado de labrar, segúnd que se contien en el dicho contracto que otorgaron en esta razón. E por ende otorgaron los dichos Johan Alfonso e Antón López, pedreros, que reçibieron del dicho Alfonso Martínez, raçionero, los dichos dos mill e quatroçientos e sesenta maravedís, ante mi, Martín Ferrández, notario público e escrivano de la dicha obra, en este día dicho.

A.C.T., O.F. 761, fol. 152 r.

\section{(1418, sábado, 4 de junio)}

En sábado, quatro días del mes de junio anno de mill e quatroçientos e dies e ocho annos, reçibieron más del dicho Alfonso Martínez, raçionero de la dicha eglesia de Toledo, los dichos Johan Alfonso e Antón López, pedreros, para conplimiento de las dichas çiento e veynte e tres cuerdas de losas prietas, que dieron e entregaron labradas dentro e puestas aquí, en Toledo, en el taller de la dicha obra, dos mill e quatroçientos e sesenta maravedís. Las dichas çiento e veynte e tres cuerdas de las dichas losas dieron para solar la eglesia e tomaron a destajo del dicho Alfonso Martínez, segúnd que se contiene en el contracto que otorgaron en esta rasón. E otorgaron que reçibieron del dicho Alfonso Martínez, raçionero, los dichos dos mill e quatroçientos e sesenta maravedís los dichos Johan Alfonso e Antón López, ante mi, el dicho Martín Ferrández, notario público e escrivano de la dicha obra, en este día susodicho.

A.C.T., O.F., f.152 v.

(1427, sábado, 21 de junio)

En el dicho día sábado, veynte e un días del dicho mes de junio del dicho anno de mill CCCCXXVII annos, dio el dicho Juan Alfonso, pedrero, dos quartos de rematamientos para los torrejones de los botareles de la cabesçera de la eglesia, esquadrados e bovados e entallados, apreçiado cada uno en quinientos maravedís que son mill maravedís.

Iten dio más siete piedras, las quatro en que vien las armas del rey e las tres piedras en que vien las armas del arçobispo don Johan, esquadradas e bovadas e entalladas, apreçiadas cada piedra en dosientos maravedís, que son mill e quatroçientos maravedís. Esto para la torre del relox.

Dio más un ligador de piedra blanco de Regachuelo para los pilares de los botareles en que ovo dos cuerdas, a dies e seys maravedís la cuerda, que son treynta e dos.

A.C.T., O.F. 765 , f. 167 v.

(1428, martes, 9 de marzo)

\section{Johan Alfonso el moço, fijo de Ferrant Alfonso, maestro de la obra}

Dio el dicho Johan Alfonso el moço, en martes, nueve días de março anno de mill e quatroçientos e veynte e ocho annos, una vasa de piedra blanca del cunno de dentro que façe responso a amas partes de los torrejones para la torre de las canpanas, esquadradas e bovadas, apreçiadas en treçientos maravedís.

Iten, dio más otra basa del panno derecho de piedra blanca para la dicha torre, apreçiada en dosientos e çinquenta maravedís, escuadrada e bovada.

Iten, dio más otra basa derecha que remata en ella a la parte del fusillo de piedra blanca para la dicha torre, esquadrada e bovada, apreçiada en çiento e sesenta maravedís.

Iten, dio más ocho pieças de piedra, en que vienen las armas del rey en algunas dellas e en otras vienen las armas del arçobispo, para la torre del relox, escuadradas e bovadas e entalladas, apreçiada cada una de ellas en dosientos maravedís, que son mill e seysçientos maravedís.

(1428, viernes, 4 de junio)

Viernes, quatro días del mes de junio, anno de mill e quatroçientos e veynte e ocho annos, dio el dicho Johan Alfonso, fijo del maestro Ferrand Alfonso, pedrero, una vasa de las derechas para los boçeles derechos 
de la piedra blanca para la torre de las canpanas, escuadrada e bovada, apreçiada en doçientos e çinquenta maravedís.

A.C.T., O.F. 766, f. 181 v.

(1429, jueves, 27 de octubre)

(Talla de pedreros).

Johan Alfonso el moço, fijo del maestro Ferrand Alfonso.

Jueves, beynte e siete días de otubre, anno de mill quatroçientos e veynte e nueve annos, este día dio el dicho Johan Alfonso, pedrero, esta talla que se sigue. Primeramente dio siete piedras blancas de Regachuelo de las armas del sennor arçobispo don Johan para la torre de las canpanas, que se asentaron en las piedras prietas de la dicha torre, escuadradas e bovadas e entalladas, apreçiado cada uno escudo de las dichas armas a dosientos maravedís, que son mill e quatroçientos maravedís.

Iten, entalló más quatro leoncillos de las armas del thesorero para la torre del relox, esquadrados e bovados e entallados, apreçiado cada uno a çinquenta, que son dosçientos maravedís.

Iten, dio más quatro piedras de las armas del dicho thesorero para la torre de las canpanas, para las asentar en los rincones en las piedras prietas, escuadradas e bovadas e entalladas, apreçiadas cada una a ochenta maravedís, que son tresientos e veynte maravedís.

Dio más una piedra prieta de las de la cantera del Regachuelo, arrancó e desbarató della por quanto la troxo a la obra para la torre de las canpanas, apreçiada en çient maravedís.

Dio más tres cuerdas e tres palmos de las chapas de Regachuelo que corren ençima de la çinbra de las piedras prietas de la dicha torre de las dichas canpanas, escuadradas e bovadas, apreçiada la cuerda a çinquenta e çinco maravedís la cuerda, que son dosçientos e seys maravedís e dos dineros e medio.

Iten, dio más dos capiteles para la torre de las canpanas de las de Regachuelo, escuadradas e bovadas e entalladas, apreçiado cada uno a tresientos e çinquenta maravedís, que son seteçientos maravedís.

Dio más quatro çimasios que vien ençima de los capiteles derechos de la dicha torre de las canpanas, escuadradas e bovadas, en que ovo çinco cuerdas e media, apreçiada la cuerda a sesenta maravedís, que son tresyentos e treynta maravedís.

A.C.T., O.F. 767 , f. 172 r.

(1431, martes, 13 de marzo)

Martes, treçe días de março de mill e quatroçientos e treynta e un annos, dio el dicho Johan Alfonso, pedrero, una piedra blanca de Regachuelo de las armas del thesorero para la torre de las canpanas, escuadrada e bovada e entallada, apreçiada en ochenta maravedís.

A.C.T., O.F. 768 , f. 153 v.

\section{(1431, sábado 31 de marzo)}

\section{Johan Alfonso, fijo de Ferrand Alfonso, maestro}

Sábado, treynta e un días de março anno de M CCCC XXXI annos, dio el dicho Johan Alfonso, pedrero, de la piedra berroquenna de la cantera de Guadaxaras para la torre de las canpanas nueve pieças de los rincones de la dicha torre, arrancadas e desbastadas e escuadradas e bovadas, en que ovo quatro cuerdas e un palmo, apreçiada la cuerda a dosientos e çinquenta maravedís, que son mill e sesenta e dos maravedís e çinco dineros.

Iten, dio más dos cunnos de los torrejones de la dicha torre de piedra berroquenna, arrancados e desbastados e escuadrados e bovados, en que ovo una cuerda apreçiada en çiento e sesenta maravedís.

Iten, dio tres boçeles de piedra berroquenna para la dicha torre, arrancados e desbastados e escuadrados e bovados, en que ovo una cuerda e un palmo, apreçiada la cuerda a çiento e treynta maravedís, que son çiento e sesenta e dos maravedís e çinco dineros.

Iten, dio más una cuerda e tres palmos de syllares para la dicha torre, a catorse maravedís la cuerda, que son veynte e quatro maravedís e çinco dineros.

Jueves, ocho días de novienbre, anno de M CCCC XXX I annos, dio Juan Alfonso pedrero, el moço, fijo del maestro, tres cunnos de los torrejones de piedra berroquenna de Guadaxaras para la torre de las canpanas, arrancadas e desbastadas e escuadradas e bovadas, en que ovo una cuerda e un palmo, apreçiada la cuerda en çiento e sesenta, que son dosientos maravedís.

Iten, dio más una pieça de las mayores del rincón de la dicha torre de piedra berroquenna, arrancada e desbastada e escuadrada e bovada, apreçiada la cuerda en dosientos e çinquenta maravedís, en que ovo palmo e medio, que son noventa e tres maravedís e çinco dineros.

Iten, dio más tres piedras de los boçeles derechos de la dicha torre de piedra berroquenna, arrancados e desbastados e esquadrados e bovados, en que ovo una cuerda e un palmo, a çiento e treynta maravedís la cuerda, que son çiento e sesenta e dos maravedís e çinco dineros.

A.C.T., O.F. 768, f. 191 r. 
Doc. . $^{\circ} 3$

Pagos a Juan Alfonso como oficial cantero (maestro de las obras) de la Iglesia de Cuenca

Maestro de las obras de las posesiones del refitor.

Johan Alfonso, fijo de Ferrant Alfonso, ha de aver de su salario tresientos e sesenta e seys maravedís.

A veynte e siete días de febrero di al dicho Johan Alfonso, maestro, çinquenta maravedís que le ove de dar de su ofiçio.

Iten, tiene más que deve del alquiler de las casas que tiene a las pennolas de Sant Estevan dosçientos e çinquenta maravedís

Otorgo yo, el dicho Johan Alfonso, maestro de las obras, que reçebí de vos, Miguel Martínez, raçionero, procurador de Pedro Carrillo, canónigo e refitolero, el anno deste libro sesenta e seys maravedís que ove de aver de mi offiçio el anno deste libro, e porque yo non sabía firmar rogué a Miguel Ferrández, raçionero, e a Ruy Sánches, conpannero, que firmaren aquí sus nonbres. Fecho veynte e nueve días de otubre, anno de la Natividad del nuestro sennor Ihesuchristo de mill e quatroçientos e veynte e quatro annos.

(Más adelante, en una relación de las posesiones que el cabildo tenía alquiladas encontramos lo siguiente)

Iten, tiene alquiladas unas casas que son çerca de Sant Estevan, en las Pennuelas, las quales dexó a la iglesia Alfonso Ferrández, clérigo que fue de la Melgosa, con cargo de dos anniversarios al altar mayor. Tienelas agora Johan Alfonso, maestro de las obras de la eglesia, en preçio en cada un anno de dosçientos e çinquaenta maravedís.

A.C.C. Mesa Capitular. Libros de Rentas, año 1421, s.f. 